\title{
Macro- and Micronutrient Cycling and Crucial Linkages to Geochemical Processes in Mangrove Ecosystems
}

\author{
Daniel M. Alongi
}

Citation: Alongi, D.M. Macro- and Micronutrient Cycling and Crucial Linkages to Geochemical Processes in Mangrove Ecosystems. J. Mar. Sci. Eng. 2021, 9, 456. https://doi.org/ $10.3390 /$ jmse 9050456

Academic Editor: Tracy Quirk

Received: 25 March 2021

Accepted: 20 April 2021

Published: 22 April 2021

Publisher's Note: MDPI stays neutral with regard to jurisdictional claims in published maps and institutional affiliations.

Copyright: (C) 2021 by the author. Licensee MDPI, Basel, Switzerland. This article is an open access article distributed under the terms and conditions of the Creative Commons Attribution (CC BY) license (https:/ / creativecommons.org/licenses/by/ $4.0 /)$.
Tropical Coastal \& Mangrove Consultants, 52 Shearwater Drive, Pakenham, VIC 3810, Australia; dmalongi@outlook.com; Tel.: +61-4744-8687

\begin{abstract}
High mangrove productivity is sustained by rapid utilization, high retention efficiency and maximum storage of nutrients in leaves, roots, and soils. Rapid microbial transformations and high mineralization efficiencies in tandem with physiological mechanisms conserve scarce nutrients. Macronutrient cycling is interlinked with micronutrient cycling; all nutrient cycles are linked closely to geochemical transformation processes. Mangroves can be N-, $\mathrm{P}-$-, $\mathrm{Fe}-$-, and $\mathrm{Cu}$-limited; additions of $\mathrm{Zn}$ and Mo stimulate early growth until levels above pristine porewater concentrations induce toxicity. Limited nutrient availability is caused by sorption and retention onto iron oxides, clays, and sulfide minerals. Little $\mathrm{N}$ is exported as immobilization is the largest transformation process. $\mathrm{Mn}$ and $\mathrm{S}$ affect $\mathrm{N}$ metabolism and photosynthesis via early diagenesis and $\mathrm{P}$ availability is coupled to Fe-S redox oscillations. Fe is involved in nitrification, denitrification and anammox, and Mo is involved in $\mathrm{NO}_{3}{ }^{-}$reduction and $\mathrm{N}_{2}$-fixation. Soil $\mathrm{Mg}, \mathrm{K}, \mathrm{Mn}, \mathrm{Zn}$ and $\mathrm{Ni}$ pool sizes decrease as mangrove primary productivity increases, suggesting increasing uptake and more rapid turnover than in less productive forests. Mangroves may be major contributors to oceanic Mn and Mo cycles, delivering 7.4-12.1 $\mathrm{Gmol} \mathrm{Mn} \mathrm{a}^{-1}$ to the ocean, which is greater than global riverine input. The global Mo import rate by mangroves corresponds to $15-120 \%$ of Mo supply to the oceanic Mo budget.
\end{abstract}

Keywords: biogeochemistry; ecosystem; geochemistry; mangrove; metals; nutrients; nutrient cycling; trace elements

\section{Introduction}

Mangroves inhabit the intertidal zone between land and sea and are located along quiescent subtropical and tropical coastlines [1]. These forested wetlands are arguably the most productive ecosystems in the sea, requiring a concomitant amount of $\mathrm{CO}_{2}$ and nutrients to sustain them. They are characterized by a rich mixture of marine and terrestrial organisms that form unique food webs and play an important role in linking inorganic and organic elements, food webs, and biogeochemical and geochemical cycles between low-latitude coasts and the adjacent coastal ocean [2].

Like other wetlands, mangrove productivity is driven by many factors, such as salinity, temperature, tides, soil nutrient status, and anoxia that imposes physiological constraints on rates of photosynthesis, respiration, gas exchange and in achieving a balance between carbon gain and water loss. Anoxia is important as without sufficient oxygen, belowground roots must rely on internal transport of gases to satisfy their oxygen requirements; geochemical conditions play an important but often overlooked role as low redox conditions make some macro- and micronutrients more available, and others less available, for plant uptake. Furthermore, some microbial metabolites, such as $\mathrm{H}_{2} \mathrm{~S}$, reduced iron (FeS) and other trace elements and organic acids produced under anoxic and suboxic conditions, are toxic to plants [3]. The presence of salt leads to mangroves utilizing one or more strategies whereby they absorb some sodium $(\mathrm{Na})$ and chloride $(\mathrm{Cl})$ ions but control uptake sufficiently to maintain an acceptable water balance.

Maintaining water balance in waterlogged, saline soil presents the problem of trying to take up sufficient inorganic ions to maintain osmotic balance yet avoiding the adverse 
effects of high ionic concentrations in the cytoplasm [3]. Mangroves utilize an advantageous strategy of minimizing water loss and maximizing carbon gain via high water-use efficiency and low transpiration rates to maximize growth. Many mangroves have traits that are consistent with adaptation to growth under low-nutrient conditions, such as sclerophylly, high root/shoot ratios, high nutrient-use efficiency, and high retention rates. However, mangroves are highly plastic in their ability to achieve rapid growth to exploit nutrients when they are not limiting while also being highly adaptable in acquiring and conserving nutrients. Mangrove photosynthesis and productivity and ecosystem functioning are thus closely intertwined with soil physiochemistry, microbial biogeochemistry, and geochemical cycles. For example, many bacterial groups in mangrove soils are not only intricately involved in nitrogen $(\mathrm{N})$ cycling but also play a key role in iron (Fe), sulfur $(\mathrm{S})$ and phosphorus (P) cycling and interlinkages between one or more of these cycles [4].

The growth and production of all plants is limited by micro- and macronutrients, with actual limitations and availability depending on habitat and environmental circumstances [5]. Mangroves, like other trees, have a requirement for various minerals to synthesize cell contents to manufacture structural and reproductive tissues [6]. Depending on the actual element, about $82-95 \%$ of the different nutrient pools are stored in the soil and not in the trees or adjacent waterways [7,8]. Furthermore, like all plants, mangroves obtain their essential nutrients from the interstitial water and little, if any, from overlying tidal waters $[3,6]$. Biogeochemical and geochemical processes of nutrient elements in mangrove soils are thus crucial in understanding the factors affecting nutrient availability to the forest.

The macronutrients required are nitrogen $(\mathrm{N})$, phosphorus $(\mathrm{P})$, sulfur $(\mathrm{S})$, magnesium $(\mathrm{Mg})$, calcium $(\mathrm{Ca})$, and potassium $(\mathrm{K})$. The micronutrients are iron $(\mathrm{Fe})$, manganese $(\mathrm{Mn})$, Copper $(\mathrm{Cu})$, Zinc, $(\mathrm{Zn})$, nickel $(\mathrm{Ni})$, molybdenum $(\mathrm{Mo})$, boron $(\mathrm{B})$, chloride $(\mathrm{Cl})$, sodium $(\mathrm{Na})$, silicon (Si), cobalt (Co), selenium (Se), and aluminum (Al). As mangroves live an estuarine to fully marine existence, they are rarely limited by the relatively large quantities of $\mathrm{S}, \mathrm{B}, \mathrm{K}, \mathrm{Mg}$, and $\mathrm{Na}$ in seawater $[3,6]$. This review explores what is known about nutrient cycling in mangrove ecosystems but focuses further on the role trace nutrients and soil geochemical processes play in the ecological energetics of these unique ecosystems. The importance of this latter role has often been overlooked in considering factors controlling nutrient use and availability in these low-latitude, low-nutrient environments.

\section{Limiting Nutrients: $\mathbf{N}$ and $\mathbf{P}$ Cycling}

Liebig's law of the minimum, often simply called Liebig's law or the law of the minimum, is a principle developed in agricultural science by Carl Sprengel (1840) and later popularized by Justus von Liebig. It states that growth is dictated not by total resources available, but by the scarcest resource (limiting factor) such as macro- and micronutrients. Globally, N and P are the two elements that immediately limit, in a Liebig sense, the growth of photosynthetic organisms. Silicon can be a limiting macronutrient, particularly for diatom growth (Section 5). Most data on nutrient cycling in mangroves therefore detail a number of $\mathrm{N}$ and $\mathrm{P}$ transformation processes and their impacts on plant and faunal growth, physiological processes, and $\mathrm{N}$ and $\mathrm{P}$ cycling in soils and tidal waterways $[1,2,6]$.

\subsection{Nitrogen}

Mangroves have a critical need for $\mathrm{N}$ since it is a major blocking block of amino acids and proteins. This requirement has been demonstrated repeatedly in laboratory culture and fertilization experiments that have revealed $\mathrm{N}$ limitation in forests dominated by a variety of species in different geomorphological settings [1] (p. 38) [6]. As $\mathrm{N}$ is often limiting, mangroves have evolved a variety of mechanisms and strategies to retain and conserve available $\mathrm{N}$, including (1) highly efficient solute uptake among trees, microbes and soil pools, (2) high rates of leaf resorption and use efficiency, (3) low rates of $\mathrm{N}$ loss such as dissolved $\mathrm{N}$ export and gas emissions in proportion to $\mathrm{N}$ inputs, (4) export of highly refractory $\mathrm{N}$ in the form of humic and fulvic acids, (5) rapid rates of $\mathrm{N}_{2}$-fixation at the soil surface 
and on various forests components (bark, downed timber, prop roots, pneumatophores, cyanobacterial mats), and (6) a large reservoir of dead roots belowground [9].

Mangrove ecosystems rely greatly on the efficiency of microbial communities in both soil and overlying waters to rapidly process, transform, and conserve various forms of $\mathrm{N}$. Soil and planktonic microbial (mostly bacteria and archaea) communities are highly diverse and abundant, to the extent that dissolved $\mathrm{N}$ pools turnover rapidly, usually in minutes to hours. Experimental addition of labile $\mathrm{N}$ to mangroves in the field or in laboratory culture results in rapid uptake and utilization, usually in the form of $\mathrm{NH}_{4}{ }^{+}$and/or $\mathrm{NO}_{3}{ }^{-}$via roots, although patterns of usage can be complex due to interactive factors, such as soil texture and type (mud, muddy sand, sand), redox status (anoxic, oxic, suboxic), species composition, intertidal position, salinity, soil geochemistry, and forest development stage.

Dissolved organic and inorganic $\mathrm{N}$ concentrations are low in mangrove tidal waters, usually in the micromolar range, and dominated by DON, followed by $\mathrm{NH}_{4}{ }^{+}, \mathrm{NO}_{3}{ }^{-}$and $\mathrm{NO}_{2}{ }^{-}$[1]. The main drivers of concentration changes are phytoplankton and bacterioplankton uptake, rainfall, land runoff, offshore marine intrusions, groundwater inputs, leaching from litter, temperature, salinity, and anthropogenic inputs [2]. Concentrations in soil interstitial water vary similarly, depending on uptake and release by mangrove roots and other biota, soil particulate $\mathrm{N}$ concentrations, soil texture and redox, presence of sulfides and other reduced elements, rates of microbial transformation processes, salinity, temperature, bioturbation, and rates of organic matter accumulation. Most DON is refractory, composed of humic acids, aromatic compounds, peptides, and amino acids [1]

Experimental and circumstantial evidence points to both interstitial $\mathrm{NO}_{3}{ }^{-}$and $\mathrm{NH}_{4}{ }^{+}$ being the main $\mathrm{N}$ species utilized by mangroves [6]. Circumstantial evidence comes from significant inverse correlations between densities of live mangrove roots and porewater $\mathrm{NH}_{4}{ }^{+}$concentrations as well as lower DN concentrations in mangrove soils than in adjacent mudflats [10]. These data suggest that the differences are the net result of tree uptake.

Concentrations of particulate $\mathrm{N}$ in tree components vary greatly among species and with differences in tree age, allochthonous inputs, extent of organic pollution, climate, salinity, temperature, physiological state, nutritional status, soil composition, intertidal position, and a variety of other factors. On average, total $\mathrm{N}(\mathrm{TN})$ concentrations in mangrove forests are like those in tropical terrestrial forest leaves and wood [9], except for lower root and soil $\mathrm{N}$ pools in mangroves. Mean TN stock in mangrove forests is $52.03 \mathrm{Mg} \mathrm{N}^{-1}$, with $96 \%$ stored in soil [9].

The mangrove $\mathrm{N}$ cycle is composed of a series of transformation processes conducted mostly by specialized archaea and bacteria, and to a lesser extent by fungi and protists (Figure 1). Rates of individual transformation processes vary greatly depending on forest type, microbial composition, soil nutrient status and other factors as noted above, and summarized by Alongi [9]. Gross rates of ammonification and nitrification are much greater than net rates, indicating $\mathrm{N}$ immobilization, uptake by autotrophs and the trees, or both. Anammox is as important a process as denitrification, and DNRA is nearly an equivalent process to net ammonification. $\mathrm{N}_{2}$-fixation rates are highest on algal/fungal/bacterial crusts growing on the bark of tree stems (Table 1), although only a few measurements have been made [9]. Rates of $\mathrm{N}_{2}$-fixation on pneumatophores and prop roots are greater than on the soil surface, litter, leaves and microbial mats; rates in belowground roots and rhizomes are likely underestimates as fixation is probably occurring in deep roots than have not been measured. Transformation rates vary widely, underscoring the fact that there are many drivers of microbial and plant $\mathrm{N}$ metabolism, including temperature, soil fertility, microbial community structure and composition, root activities, bioturbation, redox, intertidal position, and salinity. Evidence exists of other recently discovered, Ntransforming archaeal and bacterial functional groups, but no rate data are available for their activities, such as methane denitrification, nitrite oxidation, and phototrophic nitrate oxidation $[4,11]$. 


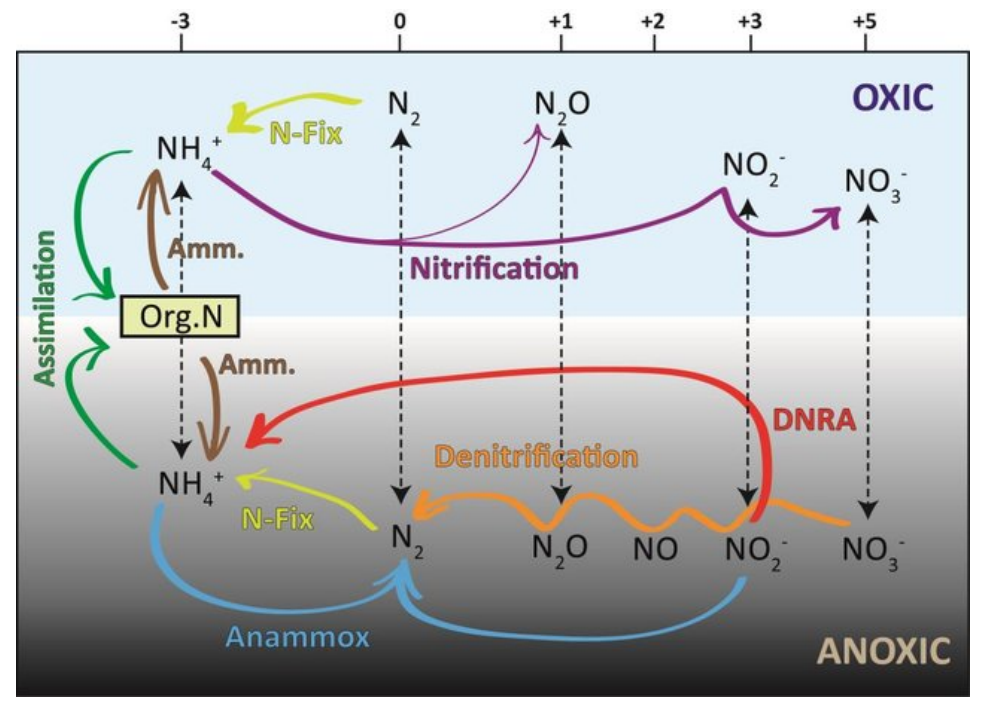

Figure 1. The $\mathrm{N}$ cycle showing all oxidizing and reducing transformation pathways occurring in oxic and anoxic habits, particularly in waterlogged saline soils. Ammonification (brown arrows) is the microbial breakdown of organic $\mathrm{N}$ to ammonium; the reverse process is assimilation/immobilization (green arrows). Nitrification (purple arrow) is the biological oxidation of ammonium to nitrite followed by oxidation to nitrate. Microbial denitrification (orange arrows) transforms from nitrate along a series of steps to eventual release of $\mathrm{N}_{2}$ gas. Anaerobic ammonium oxidation (anammox in blue arrows) processes ammonium and/or nitrite to $\mathrm{N}_{2}$. Nitrogen fixation (yellow arrows) is the process in which atmospheric $\mathrm{N}_{2}$ is transformed by specific microbial groups to ammonium and further incorporated into organic $\mathrm{N}$.

Table 1. Rates of $\mathrm{N}$ transformation processes $\left(\mathrm{mg} \mathrm{N} \mathrm{m}^{-2} \mathrm{~d}^{-1}\right)$ in mangrove soils, including $\mathrm{N}_{2^{-}}$ fixation in soils and on various tree and forest components. All rates are to soil depths of 5-20 cm. Abbreviations: DNRA = dissimilatory nitrate reduction to ammonium; anammox anaerobic ammonium oxidation; $\mathrm{AB}=$ aboveground; $\mathrm{BG}=$ belowground. Data summarized from original references in [9]. Reproduced under the terms and conditions of the Creative Commons Attribution (CC BY) license (http:/ / creativecommons.org/licenses/by/4.0/). accessed on 8 April 2021.

\begin{tabular}{ccc}
\hline Transformation Process & Mean \pm 1 SE (Median) & Range \\
\hline Denitrification & $26.3 \pm 3.3(3.9)$ & $0-443.5$ \\
Gross ammonification & $301.6 \pm 50.9(267.4)$ & $77.4-898.8$ \\
Net ammonification & $31.4 \pm 6.2(15.4)$ & $0.17-200.0$ \\
Gross nitrification & $15.1 \pm 5.81(4.7)$ & $0-141.0$ \\
Net nitrification & $5.8 \pm 1.2(1.9)$ & $0-30.8$ \\
Anammox & $22.1 \pm 5.5(4.4)$ & $0-99.4$ \\
DNRA & $18.2 \pm 6.8(4.5)$ & $0-108.6$ \\
$\mathrm{~N}_{2}$-fixation (soil) & $8.2 \pm 1.7(3.2)$ & $0-58.9$ \\
$\mathrm{~N}_{2}$-fixation (microbial mats) & $9.7 \pm 2.6(3.4)$ & $0-60.4$ \\
$\mathrm{~N}_{2}$-fixation (AB roots) & $31.8 \pm 5.6(26.3)$ & $2.8-73.4$ \\
$\mathrm{~N}_{2}$-fixation (BG roots) & $6.2 \pm 1.7(4.5)$ & $1-26.2$ \\
N -fixation (litter) & $1.2 \pm 0.4(0.5)$ & $0.2-3.3$ \\
$\mathrm{~N}_{2}$ - fixation (dead leaves) & $0.8 \pm 0.1(0.8)$ & $0.4-1.2$ \\
$\mathrm{~N}_{2}$-fixation (stem bark) & $101.0 \pm 36.4(101.0)$ & $17.4-201.2$ \\
\hline
\end{tabular}

Only two sets of measurements were made of NO fluxes across the soil-air interface, both indicating negligible release (Table 2). Rates of $\mathrm{N}_{2} \mathrm{O}$ flux show a mean flux to the atmosphere, but a few measurements indicate net uptake by soils. Rates of all DN species indicate net uptake of solutes in light bottles, indicating uptake in overlying tidal waters by microalgae, cyanobacteria, and other autotrophs on the soil surface. Rates are highly 
variable, indicating different autotrophs and their activities in different forests, but uptake was greatest for DON.

Table 2. Estimates of net $\mathrm{NO}$ and $\mathrm{N}_{2} \mathrm{O}$ gas and dissolved nitrogen fluxes $\left(\mathrm{mg} \mathrm{N} \mathrm{m}^{-2} \mathrm{~d}^{-1}\right)$ across the mangrove soil surface and rates of DON and DIN exchange between mangrove forests and adjacent tidal waterways, including mangrove-fringed estuaries. Negative rates indicate fluxes into the soil and DN exchanges importing into the mangroves. Positive values indicate fluxes from the soil to either the overlying water or atmosphere and the exporting of DN to adjacent tidal waters. Data summarized from original references in [9]. Reproduced under the terms and conditions of the Creative Commons Attribution (CC BY) license (http:/ / creativecommons.org/licenses/by/4.0/). accessed on 8 April 2021.

\begin{tabular}{ccc}
\hline Fluxes & Mean $\pm \mathbf{1 ~ S E ~ ( M e d i a n )}$ & Range \\
\hline $\mathrm{N}_{2} \mathrm{O}$ soil-air & $0.60 \pm 0.17(0.22)$ & -11.04 \\
$\mathrm{DON}$ soil-water & $-18.29 \pm 18.14(0.00)$ & $-743-19.6$ \\
$\mathrm{NO}_{2}^{-}+\mathrm{NO}_{3}{ }^{-}$soil-water & $-4.46 \pm 1.05(-0.24)$ & $-29.04-3.36$ \\
$\mathrm{NH}_{4}^{+}$soil-water & $-1.48 \pm 2.20(-0.16)$ & $-88.7-55.19$ \\
$\mathrm{NH}_{4}^{+}$import & $-9.81 \pm 4.35(-1.57)$ & $-100.76--0.006$ \\
$\mathrm{NH}_{4}^{+}$export & $8.00 \pm 3.63(0.39)$ & $0.03-62.40$ \\
$\mathrm{NH}_{4}^{+}$net exchange & $-1.45 \pm 3.12(-0.01)$ & $-100.76-62.4$ \\
$\mathrm{DON}$ import & $-4.69 \pm 2.17(-2.87)$ & $-21.84--0.91$ \\
$\mathrm{DON}$ export & $1.45 \pm 0.33(1.37)$ & $0.08-3.27$ \\
$\mathrm{DON}^{+}$net exchange & $-1.46 \pm 1.24(0.08)$ & $-21.84-3.27$ \\
$\mathrm{NO}_{2}^{-}+\mathrm{NO}_{3}{ }^{-}$import & $-3.62 \pm 1.52(-0.73)$ & $-28.80--0.003$ \\
$\mathrm{NO}_{2}{ }^{-}+\mathrm{NO}_{3}{ }^{-}$export & $1.84 \pm 0.55(0.29)$ & $0.05-11.90$ \\
$\mathrm{NO}_{2}{ }^{-}+\mathrm{NO}_{3}{ }^{-}$net exchange & $-0.73 \pm 0.85(0.08)$ & $-28.8-11.90$ \\
\hline
\end{tabular}

Rates of $\mathrm{N}$ exchange between mangrove forests and adjacent tidal waters vary widely, as reflected in the wide range of values of DIN and DON flux (Table 2). Net mean exchange is into the forests for all DN species, although median rates show little net exchange. The magnitude and direction of exchange depends on many factors, such as tidal prism, geomorphology, climate, seasonal weather patterns, the ratio of forest to waterway area, temperature, salinity, $\mathrm{pH}$, dissolved $\mathrm{O}_{2}$ levels, and plankton metabolism. In mangrove tidal waters, $\mathrm{N}_{2} \mathrm{O}$ is released into the atmosphere, averaging ( $\pm 1 \mathrm{SE}$ ) $0.11 \pm 0.03 \mathrm{mg} \mathrm{N} \mathrm{m}^{-2} \mathrm{~d}^{-1}$ with a median of $0.02 \mathrm{mg} \mathrm{N} \mathrm{m}^{-2} \mathrm{~d}^{-1}$ and ranging from net uptake $\left(-0.06 \mathrm{mg} \mathrm{N} \mathrm{m}^{-2} \mathrm{~d}^{-1}\right)$ to net release $\left(1.32 \mathrm{mg} \mathrm{N} \mathrm{m}^{-2} \mathrm{~d}^{-1}\right)$.

An empirical model of $\mathrm{N}$ cycling in mangrove ecosystems was constructed by Alongi [9], using the mean fluxes in Tables 1 and 2 and data of aboveground and belowground pools in Table 1 and Figure 2 in [9]. Such a diagram is instructive in pinpointing the major and minor $\mathrm{N}$ pathways and transformations, and in helping to identify where further research is needed. Key assumptions made to construct the budget include (1) the use of C:N ratios of forest components, (2) the input of the total belowground root + soil pool to $\mathrm{N}$ burial was estimated by the difference between the mean $\mathrm{N}$ burial value minus the inputs from root and litter production, and (3) the differences between gross and net ammonification and nitrification represent $\mathrm{N}$ immobilization [9]. Not included are (1) direct inputs from groundwater and upstream, (2) marine and terrigenous particle flux and sedimentation, (3) faunal production and consumption, (4) dry deposition, (5) $\mathrm{N}_{2}$-fixation on tree stems, cyanobacterial mats, prop roots and pneumatophores, and $\mathrm{N}$ transformation processes occurring deeper than $20 \mathrm{~cm}$. Furthermore, mangroves differ in location, climate, forest age and many other factors that are not fully addressed but must be kept in mind when considering this idealized $\mathrm{N}$ cycle. 


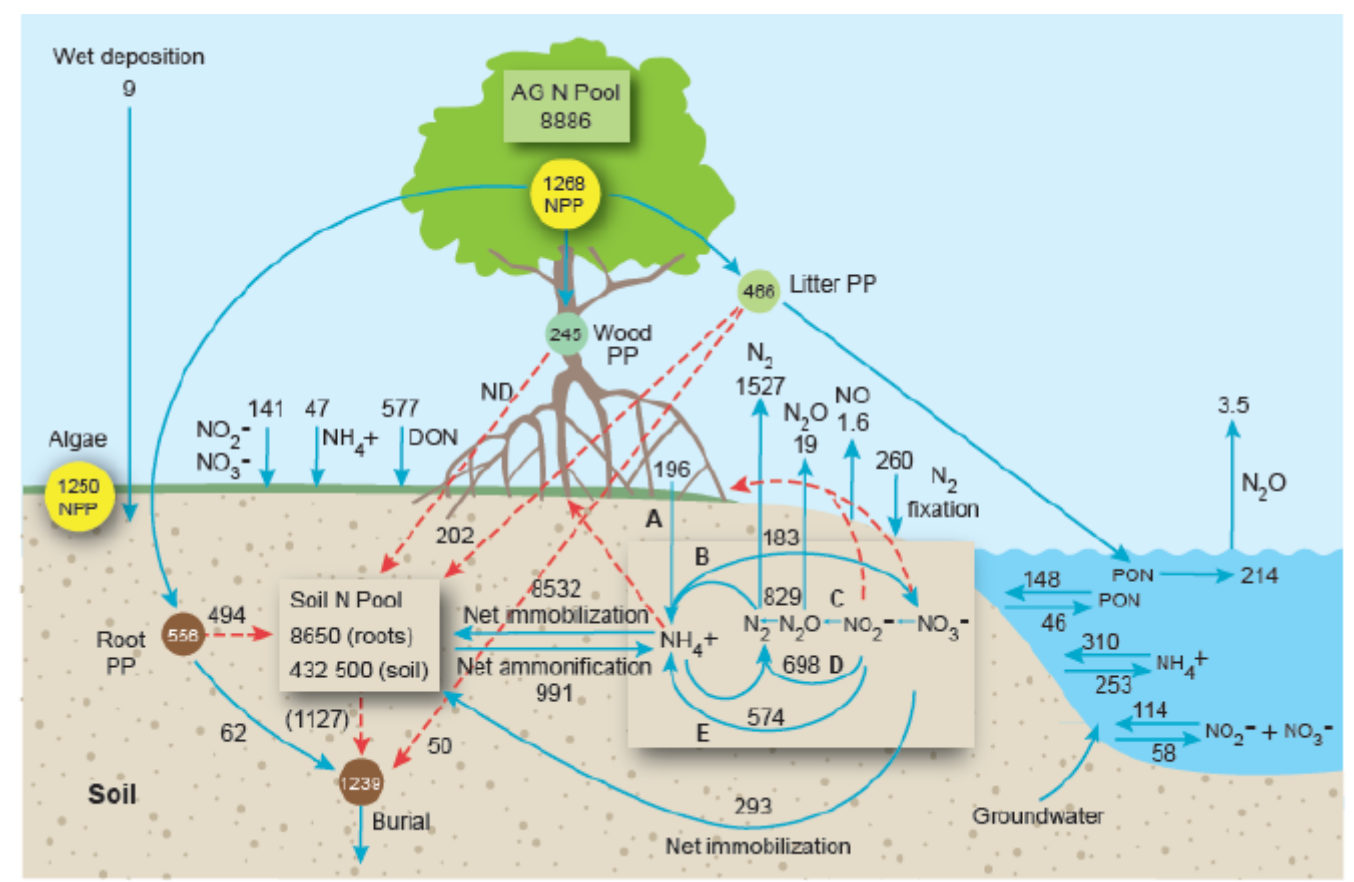

Figure 2. $\mathrm{N}$ cycling in mangrove ecosystems. Mean fluxes $=\mathrm{g} \mathrm{N} \mathrm{ha}{ }^{-1} \mathrm{~d}^{-1}$; mean standing stocks $=\mathrm{g} \mathrm{N} \mathrm{ha}^{-1}$. Soil $\mathrm{N}$ transformations are lettered as (A) root + rhizome $\mathrm{N}_{2}$-fixation, (B) net nitrification, (C) denitrification, (D) anammox, and (E) dissimilatory nitrate reduction to ammonium. Dashed red arrows represent means estimated by difference; solid blue arrows are empirical means. The roots and soil pool (box to left in the forest floor) is to a depth of $1 \mathrm{~m}$. N transformations in soil are to depths of $5-20 \mathrm{~cm}$ as presented in box on right in the forest floor. Abbreviations: ND = no data, AG N Poolaboveground forest $\mathrm{N}$ biomass pool, $\mathrm{PP}=$ primary production; $\mathrm{NPP}=$ net primary production. Modified from [9]. Reproduced under the terms and conditions of the Creative Commons Attribution (CC BY) license (http:/ / creativecommons.org/licenses/by/4.0/). accessed on 10 April 2021.

Analysis of Figure 2 illustrates several important points: (1) rates of $\mathrm{N}$ cycling and transformations are rapid, especially in the soil, (2) burial equates to $\approx 29 \%$ of total N inputs, (3) net tidal exchange of $\mathrm{DN}$ is either into the forest or near zero indicating $\mathrm{N}$ conservation, (4) anammox is as important a process as denitrification, with both accounting for $\approx 39 \%$ of total $\mathrm{N}$ input, within the range measured in other coastal ecosystems [12], (5) net immobilization ( $2702 \mathrm{~g} \mathrm{~N} \mathrm{ha}^{-1} \mathrm{~d}^{-1}$ ) is the single largest transformation indicating its significance in conserving $\mathrm{N}$, and (6) net uptake of $\mathrm{DN}$ by soils from overlying tidal waters is a significant $\mathrm{N}$ conservation mechanism, reflecting uptake by autotrophs on the soil surface. Rates of DN uptake by stems, logs, prop roots, and twigs are rapid [10,13], indicating that microbes on these surfaces also act as $\mathrm{N}$ conservators.

The budget indicates a N burial efficiency (burial/total input $\times 100$ ) of $29 \%$ and a mineralization efficiency (gross-net ammonification/total input $\times 100$ ) of $141 \%$ which will be realistically lower once inputs of $\mathrm{N}_{2}$-fixation on stem bark and other forest components are eventually included. Regardless, soil $\mathrm{N}$ appears to be very efficiently mineralized. Adding all inputs and subtracting all outputs gives a net positive gain of $303 \mathrm{~g} \mathrm{~N} \mathrm{ha}^{-1} \mathrm{~d}^{-1}$, which suggests that $\mathrm{N}$ flow in mangrove ecosystems appears to be in approximate balance, considering systematic errors and processes not included. However, once the high $\mathrm{N}_{2}$ fixation rates of tree stems, cyanobacterial mats, aboveground roots, senescent leaves, and litter are incorporated into the $\mathrm{N}$ cycle, ecosystem inputs will need to be revised upwards once further research incorporates the great spatial variability of $\mathrm{N}_{2}$-fixation on tree components. This imbalance may be redressed once consumption and assimilation of these $\mathrm{N}_{2}$-fixers by fauna is considered. A wide variety of arboreal and benthic invertebrates and fish dwell on tree stems, benthic mats, aboveground roots, leaves and litter, and readily 
consume organic particles, micro- and macroalgae, bacteria, fungi, and detritus on these forest components $[1,2]$.

Many aspects of $\mathrm{N}$ cycling need to be further quantified: (1) the need to develop a method to extrapolate the highly variable but rapid rates of $\mathrm{N}_{2}$ - fixation on stem bark, etc., to the whole-forest scale, (2) measuring $\mathrm{N}$ transformation processes in soils deeper than $20 \mathrm{~cm}$, (3) direct groundwater inputs and inputs from marine and upstream sources, (4) faunal contributions to $\mathrm{N}$ cycling, especially crabs, epiphytes and plankton, and (5) wet and dry deposition (see Section 7.3 for further discussion).

\subsection{Phosphorus}

Unlike $\mathrm{N}$ and S (Sections 2.1 and 3), which are in a reduced form in plants, $\mathrm{P}$ is found in an oxidized form as inorganic orthophosphates and pyrophosphate. $\mathrm{P}$ is actively taken up by mangrove roots, being involved in many metabolic processes, especially in transfers linked to adenosine triphosphate (ADP). $\mathrm{P}$ has an oxidation number of +5 , giving rise to a relatively simple biological cycle, but more complex geochemical-biogeochemical transformations (Figure 3).

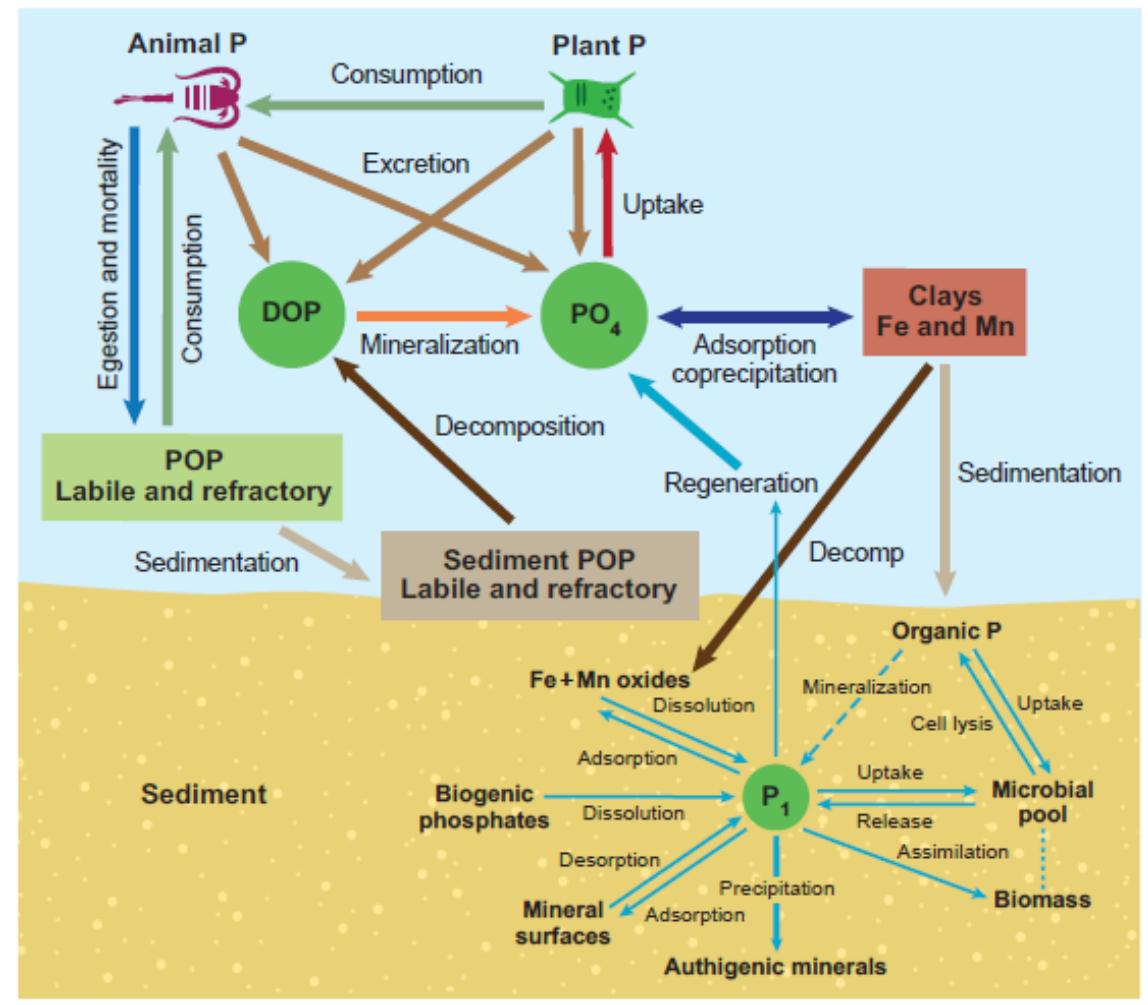

Figure 3. The P cycle showing both biotic and abiotic components including interactions with the Fe and $\mathrm{S}$ cycles.

Biologically, P is assimilated, hydrolyzed, and excreted by organisms, including mangroves, while also being involved in several adsorption, chemisorption, precipitation, and dissolution and desorption reactions (Figure 3). P availability is thus strongly dependent on the dynamics of P-Fe-S interactions (see Section 3). Phosphate $\left(\mathrm{PO}_{4}{ }^{3-}\right)$, for example, is readily absorbed and retained by $\mathrm{Fe}(\mathrm{III})$-oxyhydroxides in soils and sediments, around crab burrows, roots, and rhizospheres, limiting plant production [13]. Absorbed phosphate can, however, be released back into the porewater pool and readily available when Fe (III) oxyhydroxides are reduced under anoxic conditions. This oxidation-reduction cycle depends on movement of these complexes between oxic, suboxic, and anoxic zones, which may themselves expand or contract [13]. 
Particulate $\mathrm{P}$ in mangrove soils is in the form of Fe-P, Ca-P, Al-P, Det-P (detrital phosphate), water-soluble $\mathrm{P}$ and organic $\mathrm{P}[14,15]$. Much of the organic $\mathrm{P}$ is the phytate form and bound to humic compounds [14] and is probably not readily available for microbial and plant utilization. Total organic P concentrations reflect the influence of roots and soil detritus [14]. P is derived from several sources: (1) natural weathering and erosion of phosphate minerals, (2) dry atmospheric deposition, (3) solubilization of metal phosphates or phosphate absorbed onto clays, (4) excretion from microbes and larger organisms, and (5) anthropogenic sources (sewage, industrial effluents, agricultural runoff).

Readily available phosphate ions $\left(\mathrm{H}_{2} \mathrm{PO}_{4}{ }^{-}, \mathrm{HPO}_{4}{ }^{-}, \mathrm{PO}_{4}{ }^{3-}\right)$ tend to efficiently adsorb to clays, such as kaolinite, which is abundant in the marine tropics. Such immobilization and precipitation result in significant net removal of $\mathrm{P}$ into the large mineral pool, limiting $\mathrm{P}$ availability to mangroves $[13,14]$. Thus, it is not surprising that field studies have repeatedly observed P limitation [1] (p. 38). Ecological processes of mangroves are differentially affected by $\mathrm{N}$ versus P limitation [16]. For example, in a P-limited Avicenia germinans forest, $\mathrm{P}$ enrichment increased specific leaf area, $\mathrm{N}$ resorption and $\mathrm{P}$ uptake, but had no effect on $\mathrm{P}$ resorption. In a nearby $\mathrm{N}$-limited $A$. germinans forest, addition of $\mathrm{N}$ increased both $\mathrm{N}$ and $P$ resorption, but did not change biomass allocation; herbivory was greater at the P-limited site and was unaffected by $\mathrm{P}$ addition, whereas $\mathrm{N}$ addition led to increased herbivory at the N-limited forest [16]. Thus, N- versus P-limited mangroves have different thresholds.

Changes in soil $\mathrm{P}$ availability affect $\mathrm{N}$ cycling processes in mangroves. $\mathrm{P}$ fertilization results in stimulation of $\mathrm{N}_{2}$-fixation, as found in Rhizophora mangle forests in Belize [17]. Spatial and temporal variability positively correlated with the abundance of live roots and $\mathrm{PO}_{4}{ }^{3-}$ concentration. In nearby forests, nutrient recycling in food webs was highest for $\mathrm{P}$; mangroves and primary tree consumers were P limited, whereas invertebrates consuming leaf litter and detritus were $\mathrm{N}$ limited [18].

Availability of P can be significantly increased in mangroves by the presence of solubilizing arbuscular mycorrhizal fungi and phosphate-solubilizing bacteria [19-22]. The fact that there are many species of phosphate-solubilizing bacteria (PSB) associated with mangrove roots and rhizospheres implies that P-PSB-AMF associations may be major pathways for mangroves to acquire sufficient nutrition [17]. The mechanism responsible for microbial P solubilization in mangroves is thought to involve the production of organic acids as well as $\mathrm{H}^{+}$protonation and production of acid and alkaline phosphatases [20-22] Addition of these microbes stimulates mangrove growth and alleviates P limitation. For instance, adding arbuscular mycorrhizal fungi (AMF) to Kandelia obovata seedlings increased plant biomass, root vitality, and P uptake [19]. Soil phosphatases (enzymes that hydrolyze P esters) also play a major role in mineralizing organic P in mangrove soils; the release of these enzymes from the roots is stimulated by PSB and probably AMF [19-21]. Field studies have confirmed that both PSB and phosphatases are abundant and highly active in mangrove soils [20,22]. For example, in Avicennia marina forests in west India, phosphatase activity is highest in the rhizosphere, coinciding with peak densities of PSB and high inorganic $\mathrm{P}$, implying high bacterial conversion to inorganic forms and strong root-soil-phosphobacteria relationships [23].

Little $\mathrm{P}$ is exported from mangroves compared with inputs. A budget of $\mathrm{P}$ fluxes in Rhizophora mangle forests in Sepetiba Bay, Brazil, found that $63 \%$ of total P biomass was accumulated in the leaves and belowground roots accumulated only $16 \%$ of total $\mathrm{P}$ biomass. The annual P flux as litterfall equated to $<1 \%$ of the total soil P pool, with the annual export of $\mathrm{P}$ by microdetritus corresponding to $0.05 \%$ of the total soil reservoir [24]. Similarly, in Rhizophora mangle forests in the Potengi estuary, Brazil, 77\% of total $\mathrm{P}$ was in the soil pool, with only $23 \%$ vested in forest biomass [25]. The total P biomass pool was $145 \mathrm{~kg} \mathrm{ha}^{-1}$ with the average $\mathrm{P}$ deposition rate via litterfall to the forest floor being $12 \mathrm{~kg} \mathrm{ha}^{-1} \mathrm{a}^{-1}$, whereas P export via litter to adjacent waters was $0.5 \mathrm{~kg} \mathrm{ha}^{-1} \mathrm{a}^{-1}$. Thus, only $0.34 \%$ of forest $\mathrm{P}$ biomass was exported, indicating significant $\mathrm{P}$ retention.

A rare study of $P$ dynamics during leaf litter decomposition [26] found that the remaining $P$ in $R$. apiculata litter increased with time of decomposition to $220 \%$ of the initial 
amount in the soil, although $50 \%$ of the dry weight was lost. P incorporation into the litter was probably associated with humic acids and metal accumulation, especially caused by Fe which also accumulated in the litter. Adding leaves to the soil caused increased porewater concentrations of dissolved reactive $\mathrm{P}$ (DRP), although the DRP probably originated from Fe-bound $\mathrm{P}$ in the soil because decomposition of buried litter increased soil respiration and reduced redox conditions. Release of DRP from the soil was low due to binding to refractory organic material and oxidized Fe at the soil-water interface. Low DRP release coupled with $\mathrm{P}$ accumulation in litter result in net retention of $\mathrm{P}$ in mangroves. Like $\mathrm{N}$, $\mathrm{P}$ use and resorption efficiencies in mangroves are at the mid- to high-range measured in tropical terrestrial forests [1], indicating that the apparent strategy of using $\mathrm{N}$ and $\mathrm{P}$ efficiently is a common, perhaps evolutionary, adaptation for tropical forests $[3,6]$.

Only one P budget for a mangrove ecosystem exists [27], for the Sundarbans mangroves in India (Figure 4). P enters the mangroves via atmospheric inputs (dry deposition of aerosol + dust) at $10.5 \mathrm{Gg} \mathrm{P} \mathrm{a}^{-1}$ with aerosol emission averaging $1.4 \mathrm{Gg} \mathrm{P} \mathrm{a}^{-1}$ for a net input of $9.1 \mathrm{Gg} \mathrm{P} \mathrm{a}^{-1}$. This input is large, probably due to high pollution levels and continental air masses transporting dust over the Indo-Gangetic plain from the arid regions of western India. Forest P biomass and the soil P pools were $49.7 \mathrm{Gg}$ P, of which $97 \%$ was in biomass, although the soil pool was underestimated as only the upper $60 \mathrm{~cm}$ was measured. Litterfall $\mathrm{P}\left(6.1 \mathrm{Gg} \mathrm{P} \mathrm{a}^{-1}\right)$, dry deposition (9.1 $\left.\mathrm{Gg} \mathrm{P} \mathrm{a}^{-1}\right)$, and riverine input (0.06 $\mathrm{Gg} \mathrm{P} \mathrm{a}^{-1}$ diffusive flux and $0.8 \mathrm{Gg} \mathrm{P} \mathrm{a}^{-1}$ sedimentation of particulate $\mathrm{P}$ ) equated to a total $\mathrm{P}$ flux to the soil of $16.06 \mathrm{Gg} \mathrm{P} \mathrm{a}^{-1}$. Total removal of $\mathrm{P}$ due to plant uptake $\left(7.4 \mathrm{Gg} \mathrm{P} \mathrm{a}^{-1}\right)$, advective transport to the estuary (3.6 $\left.\mathrm{Gg} \mathrm{P} \mathrm{a}^{-1}\right)$, and export $\left(3.7 \mathrm{Gg} \mathrm{P} \mathrm{a}^{-1}\right.$ ) to the coastal ocean was $14.7 \mathrm{Gg} \mathrm{P} \mathrm{a}^{-1}$. Plant uptake accounted for $46 \%$ of the total ecosystem input; nearly $1.4 \mathrm{Gg} \mathrm{P} \mathrm{a}^{-1}$ is unaccounted for in the budget.

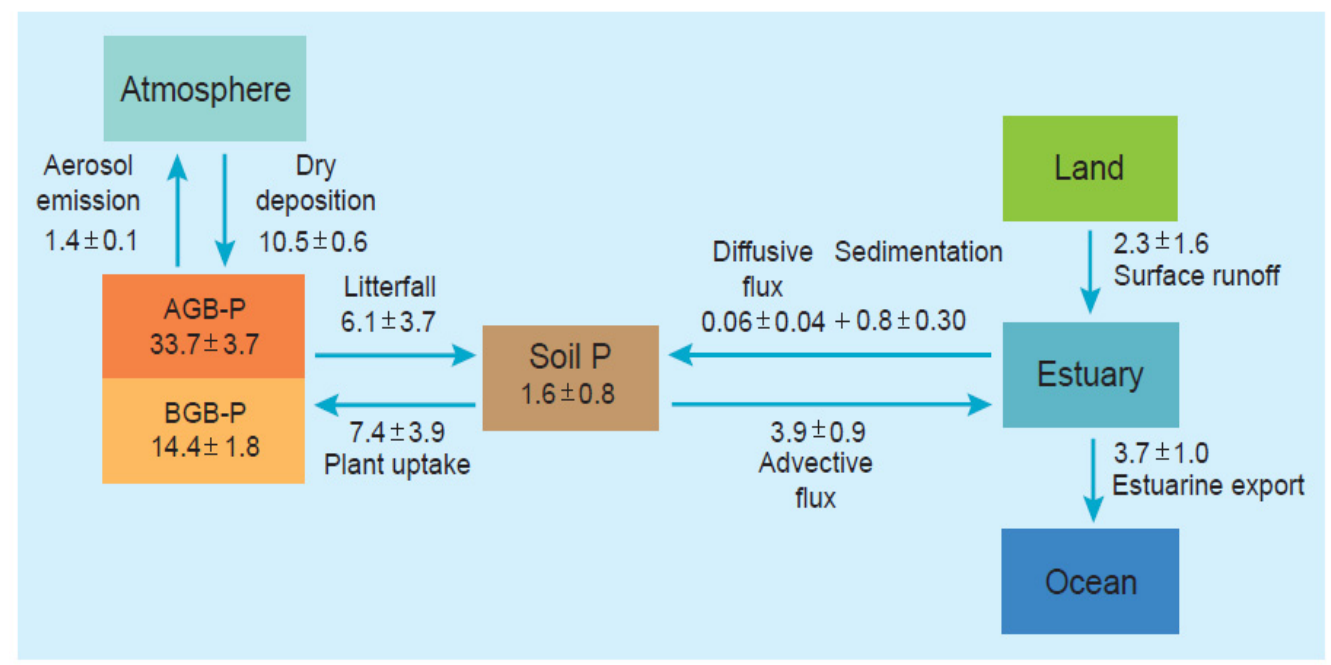

Figure 4. $\mathrm{P}$ budget for the Sundarbans mangrove ecosystem, India, covering an area of $4264 \mathrm{~km}^{2}$ of mangroves and $1781 \mathrm{~km}^{2}$ of tidal waterways. P stocks (Gg P) in aboveground (AGB-P), and belowground (BGB-P) biomass and soil $\mathrm{P}$ to a depth of $60 \mathrm{~cm}$ are presented. Fluxes are $\mathrm{Gg} \mathrm{P} \mathrm{a}^{-1}$. Source: [27]. Reproduced with permission of Springer Nature.

$\mathrm{P}$ burial was not considered in the Sundarbans budget, but $\mathrm{P}$ burial has been estimated in other mangroves [28-34], with P burial in mangrove soils averaging $4.4 \pm 1.2 \mathrm{~g} \mathrm{P} \mathrm{m}^{-2} \mathrm{a}^{-1}$ $( \pm 1 \mathrm{SE})$. Compared to global mean burial rates of $C$ and $N$ of 161.9 and $14.3 \mathrm{~g} \mathrm{~m}^{-2} \mathrm{a}^{-1}$, respectively [9,35], this gives a molar C:N:P stoichiometry of 95:7:1 for burial, which is much lower than the C:N:P stoichiometry for mangrove biomass [7,36,37] of 3405:23:1. This comparison suggests that both $\mathrm{N}$ and $\mathrm{P}$ is preferentially stored in mangrove soil relative to $\mathrm{C}$ and that $\mathrm{P}$ is preferentially stored relative to N. C and N burial equates to $12 \%$ and $44 \%$ of total net primary production [7,35]. In contrast, total mangrove NPP $\left(1757.77 \mathrm{gC} \mathrm{m}^{-2} \mathrm{a}^{-1}\right)$ [35] converted to $\mathrm{P}$ using the mangrove biomass $\mathrm{C}: \mathrm{N}: \mathrm{P}$ ratio is $0.52 \mathrm{gP} \mathrm{m}^{-2} \mathrm{a}^{-1}$, which equates 
to only $12 \%$ of $\mathrm{P}$ burial, implying that most buried $\mathrm{P}$ is derived from other sources, such as benthic microalgal, macroalgal and cyanobacterial production, terrestrial and marine sedimentation, guano and other faunal waste, and, as shown in the Sundarbans budget, atmospheric deposition as a result of biomass burning and industrial pollution.

\section{Coupled Biogeochemistry and Geochemistry: Sulfur (S) and Iron (Fe)}

Fe is a crucial micronutrient involved in chlorophyll, heme protein, and Fe-S protein production, nucleic acid metabolism, as a catalyst in $\mathrm{N}_{2}$-fixation, as an oxygen carrier, and is a structural component of porphyrin molecules $[5,6]$. Fe is considered here with $\mathrm{S}$ due to their closely interlinked geochemical cycles. $S$ is a component of the amino acids, cysteine and methionine, and the plant hormones, ethylene and polyamines, and the vitamin biotine; $\mathrm{S}$ is also involved in protein activity, and secondary metabolites, glucosinolates, and sulfated/sulfonated compounds, sulfolipids, and in ameliorating stress responses [5,6].

Both $\mathrm{Fe}$ and $\mathrm{S}$ influence $\mathrm{N}$ metabolism and photosynthesis, and $\mathrm{SO}_{4}{ }^{2-}$ and $\mathrm{Fe}$ oxides are reduced by soil microorganisms in the process of organic matter decomposition. In dissimilatory sulfate reduction, $\mathrm{SO}_{4}{ }^{2-}+2 \mathrm{CH}_{2} \mathrm{O}$ (organic matter) are reduced to $\mathrm{H}_{2} \mathrm{~S}+2 \mathrm{HCO}_{3}{ }^{-}$. In iron reduction, $\mathrm{Fe}(\mathrm{III})$ oxides + organic matter are reduced to $\mathrm{Fe}(\mathrm{II})_{\text {SOLID }}+\mathrm{Fe}(\mathrm{II})_{\mathrm{AQUEOUS}}$ and $\mathrm{CO}_{2}$. The reduction-oxidation reactions involving Fe are complex, best represented as a 'ferrous wheel' (Figure 5).

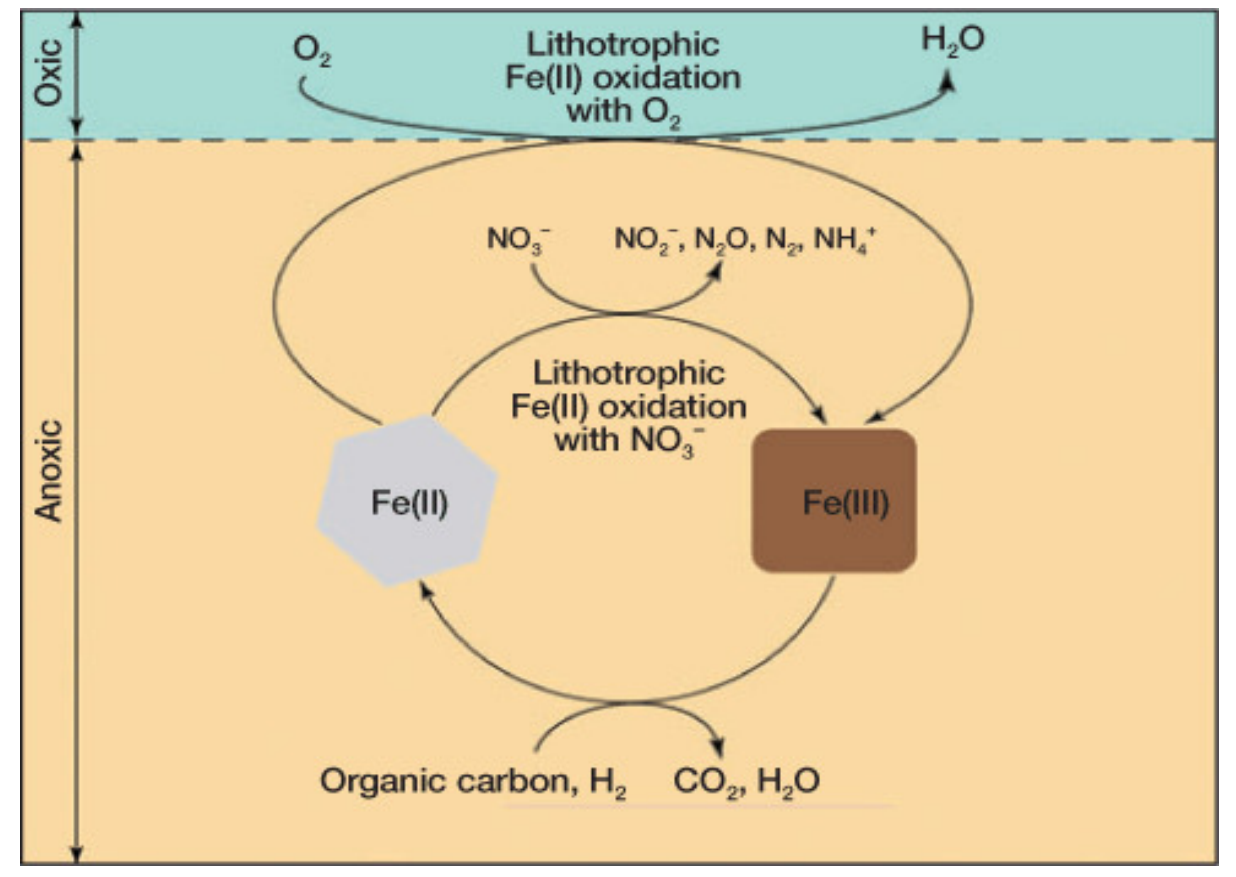

Figure 5. Iron frequently cycles rapidly between redox states, especially in wetland soils, because it is frequently used as an elector acceptor or donor in decomposing organic matter. Fe also reacts geochemically with minerals and reduction can be facilitated by humic substances that act as electron shuttles in the reduction of insoluble iron oxides. Reduced Fe (II) is then re-oxidized back to Fe (III) in contact with $\mathrm{O}_{2}$ or anaerobically via several biogeochemical processes or with nitrate possibly being reduced to several species $\left(\mathrm{N}_{2}, \mathrm{~N}_{2} \mathrm{O}, \mathrm{NH}_{4}{ }^{+}, \mathrm{NO}_{2}{ }^{-}\right)$. Fe cycling thus acts as a ferrous wheel. Source: [38]. Reproduced with permission from J. Wiley \& Sons.

Fe is thus involved in the $\mathrm{N}$ and $\mathrm{C}$ cycle. Fe and $\mathrm{S}$ are coupled to the P cycle, with implications for $\mathrm{P}$ availability [38]. Assuming fluctuations in water levels followed by periodic drying of soils, $\mathrm{Fe}, \mathrm{S}$ and $\mathrm{P}$ likely cycle in a series of redox oscillations (Figure 6). The model of Burgin et al. [38] envisions that during inundation, $\mathrm{O}_{2}$ and then $\mathrm{NO}_{3}{ }^{-}$ eventually become depleted via denitrification, and that Fe (III) reduction by anaerobic respiration produces Fe (II), releasing bound P to soil interstitial water and overlying tidal 
water (purple and bottom of pink pies, Figure 6). After oxidized $\mathrm{Fe}$ is depleted, $\mathrm{SO}_{4}{ }^{2-}$ reduction occurs and the $\mathrm{H}_{2} \mathrm{~S}$ that is produced precipitates with $\mathrm{Fe}$ (II) to form the iron sulfide minerals, mackinawite $(\mathrm{FeS})$ and pyrite $\left(\mathrm{FeS}_{2}\right)$ (pink pie, Figure 6). These minerals are relatively stable until the soil dries out, upon which oxidation to $\mathrm{FeOOH}$ strongly binds P. Chemolithotrophic bacteria mediate this process when $\mathrm{NO}_{3}{ }^{-}$is available. Under dry conditions, this oxidation process results in $\mathrm{SO}_{4}{ }^{3-}$ production (orange pie, Figure 6) with increased acidity causing mobilization of trace metals and generation of toxic forms of $\mathrm{Al}$ if $\mathrm{pH}$ is low enough (blue pie, Figure 6).

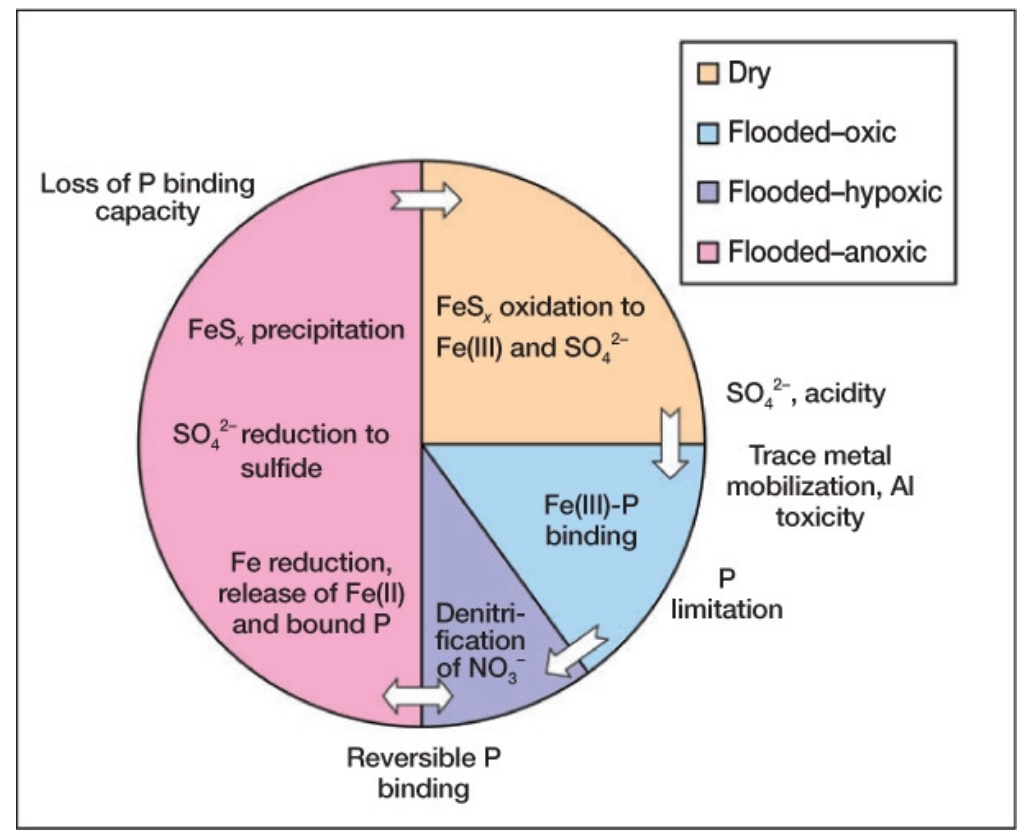

Figure 6. Model of possible changes in Fe and S cycling under dry and flooded conditions and their implications for P availability in sediments and soils. Source: [38]. Reproduced with permission from J. Wiley \& Sons.

This model is supported by empirical data from several mangrove environments $[39,40]$. In mangrove soils of the Jiulong estuary, China, labile $\mathrm{Fe}, \mathrm{S}$, and $\mathrm{P}$ distributions and variations indicate that $\mathrm{Fe}$ redox cycling plays a crucial role in regulating $\mathrm{P}$ behavior and cycling [39]. Furthermore, the flux of labile $\mathrm{S}$ increases during flood tides and decreases during ebb tides, indicating that sulfide formation and reoxidation is regulated by tide-induced redox changes [39]. Experimental addition of $\mathrm{P}$ also results in changes in Fe distribution and accumulation, including the formation of Fe plaques on mangrove roots [40,41]. Cultivating Kandelia obovataq seedlings with increasing $\mathrm{PO}_{4}{ }^{3-}$ concentrations, $\mathrm{P}$ addition decreased porewater Fe content, with higher amounts of reactive $\mathrm{Fe}$ in rhizosphere soils and higher amounts of crystalline $\mathrm{Fe}$ in nonrhizosphere soils [40]. P significantly increased Fe plaque formation and Fe accumulation in plant tissues, and $\mathrm{P}$ addition increased seedling biomass and chlorophyll content. $\mathrm{P}$ is thus implicated in Fe cycling as more reactive $\mathrm{Fe}$, more abundant root Fe-reducing and Fe-oxidizing bacteria, coupled with higher amounts of root organic acid exudation result in rapid Fe cycling in the rhizosphere $[40,41]$.

These redox oscillations are affected by the oxidizing effect of translocation and release of $\mathrm{O}_{2}$ by the roots and by downward movement of $\mathrm{O}_{2}$ during bioturbation and in the construction of animal burrows and tubes. Thus, mangrove soil is a mosaic of alternating oxic and suboxic zones near roots and biotic activities and anoxic zones in areas away from such structures and activities [13]. Redox depth profiles and spatial distribution vary with forest structure and species composition, soil type (mud, muddy sand, sand), tidal regime, and composition of benthic biota [13]. 
Fe and S biogeochemistry can be influenced by both root and bioturbation activities as experimentally shown in mesocosms with and without fiddler crabs and Avicennia marina saplings [42]. Crab activity increased the reactive oxidized $\mathrm{Fe}$ (III) in the upper centimeter of the soil, whereas $\mathrm{O}_{2}$ release by roots maintained the deeper rhizosphere oxidized and enriched in $\mathrm{Fe}$ (III). Fe reduction (FRR) was maximal in the upper centimeter of un-grazed soil. DOC leaching from roots stimulated $\mathrm{SO}_{4}{ }^{3-}$ reduction, resulting in lower $\mathrm{Fe}$ (III) and greater concentrations of $\mathrm{Fe}$ (II). Fe (III) was the most important electron acceptor for microbial carbon decomposition in un-grazed soil (63-70\%), whereas $\mathrm{SO}_{4}{ }^{3-}$ reduction (SRR) was the main pathway in grazed soil (36-44\%), especially in the presence of plants [42]. In most forest soils, FRR contributes modestly to carbon oxidation, but it has been the major decomposition pathway in a few forests [1,13].

Benthic organisms enhance Fe cycling in mangrove soils not only by bioturbation, but also indirectly by their feeding activities [43]. For example, the leaf litter feeding snail, Terebralia palustris, facilitates Fe solubilization in mangrove soils by enhancing the leaching of phenolic compounds from the leaves caused by damage from eating. Leaching promotes the solubilization of insoluble Fe in the soil by complexation with the phenolics. Phenolic compounds remaining in snail feces causes Fe solubilization by mixing between the soil and snail feces [43]. Ambient Fe concentrations in the porewater also regulate rates of SRR [44]. Addition of $50 \mathrm{ppm}$ Fe (III) in laboratory experiments increased SRR, but at $100 \mathrm{ppm}$, SRR was inhibited; at $1000 \mathrm{ppm}$ Fe (III), SRR decreased to $93 \%$ of the control. In a similar experiment, seedlings of Avicennia schaueriana, Laguncularia racemosa, and Rhizophora mangle were exposed to increasing Fe levels to evaluate Fe uptake and translocation to plant parts [45]. The results indicate species-specific differences as L. racemosa accumulated Fe in both Fe-plaque and roots, increasing with increasing amounts of $\mathrm{Fe}$, although there were no changes in rates of translocation. In contrast, A. schaueriana showed the highest Fe levels and $R$. mangle presented the low Fe levels in stems and leaves. There was a significant drop in the translocation factor between aerial roots and belowground roots since the bioaccumulation of plaque and roots of $R$. mangle increased as Fe levels rose [45].

$\mathrm{Fe}$ is coupled to the $\mathrm{N}$ cycle via nitrification, denitrification, and anaerobic ammonium oxidation [46-50]. In a forest receiving some input from ferromanganese mining in Goa, India, soil nitrification was governed by autotrophic nitrifiers at the expense of Fe [46]. With an above normal load of Fe, autotrophic nitrification was more important than nitrification by microheterotrophs. In the same estuaries in Goa, denitrification was linked to Fe concentrations, possibly as Fe-mediated nitrate respiration [47]. In other South and East Asian mangroves [48-50], anaerobic ammonium oxidation has been found to be coupled to FRR in a process named Feammox. In soil slurries from the Jiulong estuary, China, rates of Feammox averaged $0.48 \pm 0.03(1 \mathrm{SE}) \mathrm{mg} \mathrm{N} \mathrm{kg}^{-1} \mathrm{~d}^{-1}$, accounting for $6.4 \%$ of the total $\mathrm{N}$ loss through $\mathrm{N}_{2}$ [48]. When microbially reducible Fe (III) was added to slurries, the Feammox rate increased compared to controls without additional Fe. In another study [49], Feammox was detected in mangrove soils using an isotope tracing technique, contributing $1.5-4.9 \%$ of FRR.

The $\mathrm{S}$ cycle, in contrast, is linked closely to organic matter (OM) diagenesis [51,52]. In a mangrove forest in the Turks and Caicos Islands [51], abundant organic and elemental $\mathrm{S}$ with a ${ }^{34}$ S-depleted composition was measured near a root surface releasing $\mathrm{O}_{2}$, indicating microbial sulfur cycling and $\mathrm{OM}$ sulfurization (i.e., enrichment of $\mathrm{OM}$ with $\mathrm{S}$ abiotically). $\mathrm{FeS}_{2}$, elemental $\mathrm{S}$ and organic $\mathrm{S}$ formed a plaque within the outer $50 \mu \mathrm{m}$ of the root in which its xylem contained strongly ${ }^{34} \mathrm{~S}$-depleted $\mathrm{SO}_{4}{ }^{3-}$. In organic-rich mangrove soils in Guadeloupe, active SRR was driven by organic carbon oxidation [52]. Vertical and spatial variations in $S$ cycling seemed to be controlled mainly by unsteady to relatively steady OM deposition and reactivity.

Dissolved Fe can be limiting for mangrove growth [53,54]. In mesocosm experiments, five mangrove species were grown from seedling to sapling stage with increasing rates of dissolved Fe supply [53]. In all experiments, growth was enhanced as Fe supply increased, but some species showed Fe toxicity at the higher supply rates. Stem extension rates of 
Rhizophora apiculata, Bruguiera gymnorrhiza, and Xylocarpus moluccensis best fit Gaussian curves with maximal growth at supply rates of 50-60 mmol Fe $\mathrm{m}^{-2} \mathrm{~d}^{-1}$. Growth of Avicennia marina and Ceriops tagal increased to the highest rate $\left(100 \mathrm{mmol} \mathrm{Fe} \mathrm{m}^{-2} \mathrm{~d}^{-1}\right)$. In a further experiment, rates of microbial Fe reduction were greater with $R$. apiculata and $A$. marina than in controls without plants, with a positive relationship between stem extension rates and rates of Fe reduction [53]. In experiments with A. marina seedlings derived from the arid Red Sea, Fe treatment resulted in significantly taller plants compared to $\mathrm{N}$ and $\mathrm{P}$ treatments. This result was attributed to the fact that in the Red Sea, the highly tolerant $A$. marina receives limited riverine Fe input which may partly explain their dominant dwarf form. Further, A. marina in this region grows mostly on carbonates that are highly saline and poor in most nutrients required by plants.

\section{Abundant Macronutrients: Magnesium (Mg), Calcium (Ca), and Potassium (K)}

These mineral nutrients are abundant in seawater, so they are not ordinarily considered limiting for mangroves, although some deficiencies may occur in high saline environments [3,6]. Mg is required for photosynthesis and located in the enzymes within the chlorophyll molecule. $\mathrm{Mg}$ is also used for carbohydrate metabolism and cell membrane stabilization. $\mathrm{Mg}$ deficiency can occur in plants growing in organic-poor soils. Ca has many roles in mangroves, including participating in metabolic processes, promoting cell elongation, and strengthening cell wall structure ( $\mathrm{Ca}$ is an essential part of plant cell walls). It forms Ca pectate compounds giving stability to cell walls and binds cells together, participates in enzymatic and hormonal processes, helps in protecting against heat stress and disease, and plays a role in regulating stomata [3,6]. $\mathrm{K}$ is required by mangroves mainly to help regulate osmotic processes, but it also is involved in growth regulation and protein synthesis. Geochemically, mangrove soils containing significant amounts of clay are probably $\mathrm{K}$ sinks, as $\mathrm{K}$ is consumed in large quantities during rapid transformation of the clay kaolinite to Fe-illite [55].

Concentrations of these minerals in tree parts vary widely among species and locations (Table 3), likely reflecting species-specific differences in uptake and storage as well as the mineral status of the soil. It is therefore not possible to generalize which mineral is most abundant in a particular tree component. For example, in $R$. stylosa, $\mathrm{Mg}$ is most abundant in tree stems and branches, but most abundant in $R$. apiculata and A. marina leaves (Table 3). Similarly, $\mathrm{Ca}$ is stored mostly in dead roots of R. stylosa and A. marina, but mostly in leaves and branches of $R$. apiculata. The only consistent pattern appears to be storage of $\mathrm{K}$ in leaves of all three species (Table 3). Concentrations of $\mathrm{K}, \mathrm{Ca}$, and $\mathrm{Mg}$ also vary greatly among leaves of the mangrove palm, Nypa fruticans, as measured in different stands in the Philippines [56]. K was most abundant and least variable $(0.72-1.13 \% \mathrm{DW})$, whereas $\mathrm{Mg}$ was second in abundance $(0.012-0.92 \% \mathrm{DW})$ followed by Ca $(0.017-0.90 \% \mathrm{DW})$. These differences between stands related best to salinity, human activities, and soil $\mathrm{pH}$ [56].

Table 3. Mean concentrations ( $\mathrm{mg} \mathrm{g}^{-1} \mathrm{DW}$ ) of $\mathrm{Mg}$, $\mathrm{Ca}$, and $\mathrm{K}$ in different tree components in three mangrove species. Soils were sampled to the depth of maximum root penetration. $R$. stylosa and $A$. marina were in Western Australia in the arid tropics and $R$. apiculata was in southern Thailand in the humid tropics. NA = not applicable. Source: $[7,37]$.

\begin{tabular}{cccccccccc}
\hline Component & \multicolumn{3}{c}{ Rhizophora stylosa } & \multicolumn{3}{c}{ Rhizophora apiculata } & \multicolumn{3}{c}{ Avicennia marina } \\
\hline & Mg & Ca & K & Mg & Ca & K & Mg & Ca & K \\
\hline Leaves & 13.8 & 9.4 & 6.3 & 7.3 & 19.6 & 8.2 & 11 & 5.9 & 8.8 \\
Branches & 16.5 & 1.2 & 1.1 & 1.2 & 14.5 & 2.6 & 1 & 9.2 & 2.7 \\
Stems & 16.6 & 1.3 & 1 & 0.5 & 4.7 & 0.8 & 1.2 & 7.1 & 2.8 \\
Prop roots & 7.6 & 9 & 3.1 & 0.9 & 5.4 & 1.2 & & NA & \\
BG live roots & 7.9 & 8.4 & 2.4 & 4.8 & 3.4 & 1.8 & 7 & 14.6 & 3.7 \\
BG dead roots & 11.6 & 60.8 & 4.8 & 6.5 & 7.5 & 1.2 & 6.5 & 14.9 & 3.9 \\
Soil $\left(\mathrm{kg} \mathrm{m}^{-2}\right)$ & 7.4 & 38.4 & 3 & 3.2 & 1.2 & 3.5 & 10 & 34.4 & 4.4 \\
\hline
\end{tabular}


$\mathrm{Mg}$ is stored in leaves and roots and $\mathrm{Ca}$ and $\mathrm{K}$ are mostly concentrated in leaves of R. apiculata trees in Malaysia [36], whereas $\mathrm{Mg}$ is stored mostly in leaves and roots and $\mathrm{Ca}$ and $\mathrm{K}$ are stored in leaves in R.mangle trees originating from Venezuela [57]. In trees of Bruguiera parviflora in Malaysia [58], $\mathrm{Mg}$ content is greatest in roots and secondarily in leaves, whereas $\mathrm{Ca}$ and $\mathrm{K}$ are stored in leaves and roots. However, changes in element concentrations change as trees age. For instance, as leaves of R. mangle and Laguncularia racemosa age from young to senescent stage, $\mathrm{K}$ content declines, pointing to lower net transport rates (resorption) into the leaves in a process probably related to the role of $\mathrm{K}$ in nitrate transport from roots to leaves [59]. Nitrate is transported in the xylem with $\mathrm{K}$ as a counter ion, and it is likely preferentially transported to actively growing leaves causing a decline in supply and concentration into older leaves [59]. In contrast, $\mathrm{Mg}$ and Ca content increase as leaves age in both species, indicating accumulation [59].

Several mangrove species resorb $\mathrm{K}^{+}$efficiently, although resorption rates can vary within a species in response to factors such as salinity and tree age. For instance, $\mathrm{K}^{-}$ resorption efficiency in Sonneratia apetala in the Sundarbans of Bangladesh was highest $(61.3 \%)$ in the high salinity zone during the pre-monsoon, whereas the lowest efficiency $(35.0 \%)$ was measured in trees in the low salinity zone during the post-monsoon [60]; $\mathrm{K}$ resorption efficiency was highest during the high salinity period (pre-monsoon) at all sites, suggesting that as salinity increases, nutrient availability in the soil decreases and nutrient resorption efficiency increases to conserve nutrients [60]. At increasing salinity, $\mathrm{K}, \mathrm{Mg}$, and $\mathrm{Ca}$ concentrations in mangrove leaves decline [61,62]. Laboratory experiments with Avicennia marina showed that foliar $\mathrm{K}^{+}$concentrations declined with an increase in salinity, likely because high $\mathrm{Na}^{+}$concentrations can interfere with $\mathrm{K}^{+}$uptake by roots [62]. Salinity induces $\mathrm{K}$ deficiency resulting in a decline in light- and $\mathrm{CO}_{2}$-saturated rates of $\mathrm{O}_{2}$ evolution, consistent with a $24 \%$ decrease in chlorophyll content when leaf $\mathrm{K}^{+}$content declines from 379 to $167 \mathrm{~mol} \mathrm{~m}^{-3}$; at a $\mathrm{K}^{+}$content of $103 \mathrm{~mol} \mathrm{~m}^{-3}$, A. marina leaves showed drastic loss of light-and $\mathrm{CO}_{2}$-saturated photosynthetic capacity [62].

Evidence for the impact of $\mathrm{K}$ deficiency and limitation of mangrove productivity comes from two culture experiments involving seedlings and saplings of three species. In factorial experiments with $A$. marina [63], seedling growth was measured in response to different levels of N, P and $\mathrm{K}$ fertilization. The $\mathrm{N}$ and $\mathrm{P}$ treatments resulted in increased plant height, number of leaves, and branches; increasing $\mathrm{K}$ levels resulted in significantly increased number of branches per plant. A similar experiment was conducted with $A$. marina, Ceriops tagal, and Rhizophora stylosa supplied with increasing levels of N, P and K at two salinities [64]. After seven months, $\mathrm{K}$ had a significant effect on leaf production in $C$. tagal and A. marina. R. stylosa showed positive responses to $\mathrm{K}$ addition, but with significant interactive effects with $\mathrm{N}$ and P. R. stylosa showed increasing leaf extension rates with $\mathrm{K}$ and intermediate $\mathrm{P}$ concentrations, no clear change with $\mathrm{K}$ at the high $\mathrm{P}$ concentrations, and a decline in expansion rates at the low $\mathrm{P}$ concentrations, suggesting different outcomes in different environments, especially at different salinities [64].

Release and turnover rates of $\mathrm{Mg}, \mathrm{K}$, and $\mathrm{Ca}$ in mangrove soils increase and decrease, respectively, in relation to forest net primary production [65]. In the examples provided (Table 4), turnover of the soil $\mathrm{Mg}$ pool lengthens from 9.2 to 81.3 to $85 \mathrm{y}$ from a gradient of decreasing forest productivity. The same is the case for $\mathrm{K}$, which has the longest turnover times, and Ca turnover, which has the shortest turnover times (Table 4). Turnover times of $\mathrm{K}$ have been estimated in other mangroves, with turnover ranging from $9 \mathrm{y}$ in a Kandelia candel stand, $14 \mathrm{y}$ in a Bruguiera sexangula forest and $27.3 \mathrm{y}$ in a mixed Aegiceras corniculatumKandelia candel forest located in southern China [1]. Turnover was more rapid (5 y) in a productive R. apiculata forest in Malaysia and in a R. mangle forest ( $8 \mathrm{y})$ in Panama [references in 1]. In a detailed study of storage and recycling of macro- and micronutrients in mangrove forests in the Sundarbans [66], belowground uptake rates were consistently higher than litterfall fluxes by two to three-fold. Annual flux of belowground uptake ranged from 9730 to $40,260 \mathrm{mg} \mathrm{m}^{-2} \mathrm{a}^{-1}$ for the macronutrients, and from 0.21 to $586 \mathrm{mg} \mathrm{m}^{-2} \mathrm{a}^{-1}$ for the trace nutrients. Highest macronutrient flux was for $\mathrm{Na}\left(40,260 \mathrm{mg} \mathrm{m}^{-2} \mathrm{a}^{-1}\right)$, followed by 
$\mathrm{K}\left(17,240 \mathrm{mg} \mathrm{m}^{-2} \mathrm{a}^{-1}\right), \mathrm{Ca}\left(16,830 \mathrm{mg} \mathrm{m}^{-2} \mathrm{a}^{-1}\right)$ and $\mathrm{Mg}\left(9730 \mathrm{mg} \mathrm{m}^{-2} \mathrm{a}^{-1}\right)$. The trend for trace nutrients was Fe $\left(586 \mathrm{mg} \mathrm{m}^{-2} \mathrm{a}^{-1}\right), \mathrm{Al}\left(585.5 \mathrm{mg} \mathrm{m}^{-2} \mathrm{a}^{-1}\right), \mathrm{Mn}\left(332 \mathrm{mg} \mathrm{m}^{-2} \mathrm{a}^{-1}\right)$, $\mathrm{Cu}\left(240 \mathrm{mg} \mathrm{m}^{-2} \mathrm{a}^{-1}\right), \mathrm{Zn}\left(229 \mathrm{mg} \mathrm{m}^{-2} \mathrm{a}^{-1}\right), \mathrm{Ni}\left(6.2 \mathrm{mg} \mathrm{m}^{-2} \mathrm{a}^{-1}\right), \mathrm{Mo}\left(1.6 \mathrm{mg} \mathrm{m}^{-2} \mathrm{a}^{-1}\right)$ and $\mathrm{Co}\left(0.5 \mathrm{mg} \mathrm{m}^{-2} \mathrm{a}^{-1}\right)$. Typical turnover time was between 10 and $28 \mathrm{y}$, with a trend of shorter turnover in more productive species [66]. These data indicate that productive mangroves have greater need for $\mathrm{Ca}, \mathrm{Mg}$ and $\mathrm{K}$, as reflected by greater uptake and more rapid turnover of their soil pools, than in less productive forests.

Table 4. Soil $\mathrm{Mg}$, Ca, and $\mathrm{K}$ inventories $\left(\mathrm{kg} \mathrm{m}^{-2}\right)$, release rates $\left(\mathrm{kg} \mathrm{m}^{-2} \mathrm{a}^{-1}\right)$, and turnover times (a) in 25-, 5- and 3-year-old Rhizophora apiculata forests in southern Thailand. Soils were sampled to depth of maximum root penetration. AG NPP $\left(\mathrm{kg} \mathrm{C} \mathrm{m}^{-2} \mathrm{a}^{-1}\right)=$ aboveground net primary production. Source: [65].

\begin{tabular}{cccccccccc}
\hline Component & \multicolumn{3}{c}{ 25-Year-Old Forest } & \multicolumn{3}{c}{ 5-Year-Old Forest } & \multicolumn{3}{c}{ 3-Year-Old Forest } \\
\hline & $\mathbf{M g}$ & $\mathbf{C a}$ & $\mathbf{K}$ & $\mathbf{M g}$ & $\mathbf{C a}$ & $\mathbf{K}$ & $\mathbf{M g}$ & $\mathbf{C a}$ & $\mathbf{K}$ \\
\hline Inventory & 1.68 & 0.46 & 2.17 & 2.2 & 2.22 & 2.99 & 3.19 & 1.17 & 3.48 \\
Release & 0.29 & 0.25 & 0.1 & 0.03 & 0.06 & 0.02 & 0.04 & 0.15 & 0.05 \\
Turnover & 9.2 & 1.9 & 21.1 & 85 & 39.6 & 126.9 & 81.3 & 7.8 & 63.8 \\
AG NPP & & 5.3 & & & 1.7 & & & 3.7 & \\
\hline
\end{tabular}

\section{Silicon Requirements}

$\mathrm{Si}$ is not considered an essential macronutrient for plant development and growth, but it is needed to sustain primary productivity of various marine pelagic and benthic autotrophs, such as silicoflagellates and diatoms. In mangrove forests, Si is involved in several key processes, including being a constituent of trees and algae, and being taken up by various autotrophs living on the soil surface, on downed timber, and on aboveground roots, stems, and branches [10]. Si strengthens cell walls and improves plant health and productivity as demonstrated in crops such as rice [5]. Si accumulation occurs in mangrove roots via a regulatory serine-rich protein [67] where it helps to alleviate heavy metal toxicity [68].

Si may not be a key nutrient for mangrove nutrition, but it is found in large quantities in soils in insoluble form and in interstitial water and in overlying tidal water as $\mathrm{H}_{4} \mathrm{SiO}_{4}$ (orthosilicic acid), which is readily taken up by various phytoplankton in mangrove creeks and waterways and by various flora living on the forest floor and on the trees. In a mixed Rhizophora forest on Hinchinbrook Island, Australia, low-, mid- and high-intertidal forests recycled large amounts of dissolved Si [10]. In the high-intertidal forest, soils released $6150 \mathrm{mmol} \mathrm{Si} \mathrm{ha}^{-1} \mathrm{~d}^{-1}$ to overlying tidal waters but were not considered further due to their small area ( $9 \%$ of total forest area). In the low-intertidal forest, trunks and soils released 250 and $3200 \mathrm{mmol} \mathrm{Si} \mathrm{ha}^{-1} \mathrm{~d}^{-1}$, respectively, and prop roots imported $975 \mathrm{mmol}$ $\mathrm{Si} \mathrm{ha}{ }^{-1} \mathrm{~d}^{-1}$, for a net export of $2475 \mathrm{mmol} \mathrm{Si} \mathrm{ha}{ }^{-1} \mathrm{~d}^{-1}$. In the mid-intertidal forest, trunks exported $175 \mathrm{mmol} \mathrm{Si} \mathrm{ha}{ }^{-1} \mathrm{~d}^{-1}$, but prop roots and soils imported 2745 and $1800 \mathrm{mmol}$ Si ha ${ }^{-1} \mathrm{~d}^{-1}$, respectively, for a net forest import of $4720 \mathrm{mmol} \mathrm{Si} \mathrm{ha}^{-1} \mathrm{~d}^{-1}$. For the entire forested area, there was a net import of $14,337 \mathrm{~kg} \mathrm{Si} \mathrm{a}^{-1}$. In comparison, dissolved $\mathrm{N}$ and $\mathrm{P}$ are imported into the forests at rates of 3275 and $791 \mathrm{~kg} \mathrm{a}^{-1}$, respectively. These figures indicate that these tidally dominated mangrove forests are a large and efficient sink for Si [10].

\section{Micronutrients}

Micronutrients are readily utilized by mangroves for a variety of physiological and biochemical processes but are required only in trace amounts; high levels of most elements result in toxicity and/or a decline in plant growth and viability. $\mathrm{Na}$ and $\mathrm{Cl}$ are not considered here as they are involved primarily in salt regulation and other physiological processes reviewed extensively earlier [3,6]. Se, Al and B are also not considered as there 
are no data on their role in mangrove nutrient cycling; the only empirical data for these three elements relate to concentrations in soil and in some tree parts, notably leaves.

\subsection{Manganese (Mn)}

Mn is an essential micronutrient required for plant growth, being involved in chloroplast formation, photosynthesis, $\mathrm{N}$ metabolism and synthesis of riboflavin, ascorbic acid, carotene, and some enzymes [3,5,6]. Mn concentration in tree components is greatest in leaves, followed by dead and live roots [7,8,37,56-58]. The percentage of Mn vested in total living biomass of $R$. apiculata decreased with increasing forest age, from 4 to 2 to $1 \%$ in 25,5 , and 3-year-old stands [8]. As with all other elements, most Mn is stored in soils [7,37,56-58]. Additionally, like $\mathrm{Mg}$, $\mathrm{Ca}$, and $\mathrm{K}$, turnover of the soil $\mathrm{Mn}$ pool lengthens from $2.7 \mathrm{y}$ to $13.7 \mathrm{y}$ to $119.7 \mathrm{y}(\mathrm{y}=$ year $)$ from the most productive to the least productive mangroves, reflecting a forest requirement for $\mathrm{Mn}$ (Table 5).

Table 5. Soil $\mathrm{Mn}, \mathrm{Cu}, \mathrm{Zn}$, and Mo inventories $\left(\mathrm{g} \mathrm{m}^{-2}\right)$, release rates $\left(\mathrm{g} \mathrm{m}^{-2} \mathrm{a}^{-1}\right)$, and turnover times (a) in 25-, 5-, and 3-year old Rhizophora apiculata forests in southern Thailand. Soils were sampled to depth of maximum root penetration. AG NPP $\left(\mathrm{kg} \mathrm{C} \mathrm{m} \mathrm{m}^{-2} \mathrm{a}^{-1}\right)$ aboveground net primary production. Source: [65].

\begin{tabular}{|c|c|c|c|c|c|c|c|c|c|c|c|c|}
\hline \multirow[t]{2}{*}{ Component } & \multicolumn{4}{|c|}{ 25-Year-Old Forest } & \multicolumn{4}{|c|}{ 5-Year-Old Forest } & \multicolumn{4}{|c|}{ 3-Year-Old Forest } \\
\hline & Mn & $\mathrm{Cu}$ & $\mathrm{Zn}$ & Mo & Mn & $\mathrm{Cu}$ & $\mathrm{Zn}$ & Mo & Mn & $\mathrm{Cu}$ & $\mathrm{Zn}$ & Mo \\
\hline Inventory & 89.5 & 3.9 & 12.7 & 1.6 & 230.5 & 3 & 19.2 & 3.1 & 120.5 & 2.8 & 19.8 & 4.1 \\
\hline Release & 33.4 & 0.006 & 0.08 & 0.06 & 1.9 & 0.006 & 0.03 & 0.01 & 8.8 & 0.02 & 0.04 & 0.01 \\
\hline Turnover & 3 & 610 & 162 & 28 & 120 & 470 & 733 & 320 & 14 & 147 & 505 & 430 \\
\hline AG NPP & \multicolumn{4}{|c|}{5.3} & \multicolumn{4}{|c|}{1.7} & \multicolumn{4}{|c|}{3.7} \\
\hline
\end{tabular}

Microbes in anaerobic mangrove soils couple the reduction of manganese oxides $\left(\mathrm{MnO}_{2}\right)$ to the oxidation of organic matter in a process called dissimilatory manganese reduction (MRR), which results in the production of $\mathrm{CO}_{2}$ and $\mathrm{Mn}^{2+} \cdot \mathrm{Mn}^{2+}$ is rapidly involved in a series of oxidation and reduction reactions such as those undertaken by Fe. MRR has been measured in some mangroves, with rates indicating a minor to moderate (2-30\% of total carbon decomposition) role in organic matter diagenesis [1]. In both Indian and Chinese mangroves, MRR rates coincided with peak densities of live roots suggesting a dynamic link between Mn cycling and tree activities [69,70]. Rates of MRR in the Indian (mean $=57 \mathrm{mmol} \mathrm{m}^{-2} \mathrm{~d}^{-1}$ ) forests were greater than rates of $\mathrm{Fe}$ reduction (mean $=7 \mathrm{mmol} \mathrm{m}^{-2} \mathrm{~d}^{-1}$ ) but the opposite was found in the Chinese forests $\left(\right.$ MRR mean $=16 \mathrm{mmol} \mathrm{m}^{-2} \mathrm{~d}^{-1} ;$ FRR mean $=28 \mathrm{mmol} \mathrm{m}^{-2} \mathrm{~d}^{-1}[69,70]$.

Of potentially greater importance is the role of dissolved manganese exported from mangroves to the coastal ocean. Dissolved $\mathrm{Mn}$ is in high abundance in mangrove soils and is readily released to the overlying tidal water [71,72] with flux rates across the soilwater interface ranging from 195-1860 $\mu \mathrm{mol} \mathrm{m}^{-2} \mathrm{~d}^{-1}$ ([72] Table 5). Measuring porewater exchange of Mn from several mangrove ecosystems along a latitudinal gradient in Australia, Holloway et al. [72] found that the average Mn export rate from these mangrove systems to the adjacent coastal ocean was $88 \mathrm{kmol} \mathrm{km}^{-2} \mathrm{a}^{-1}$. Extrapolating to both the low and high estimates of global mangrove area $\left(84,500\right.$ and $\left.140,000 \mathrm{~km}^{2}\right)$, mangroves may deliver 7.4-12.1 $\mathrm{Gmol} \mathrm{a}^{-1}$ of dissolved $\mathrm{Mn}$ to the coastal ocean. These export estimates are greater than the estimated inputs from global rivers $\left(5.4 \mathrm{Gmol} \mathrm{a}^{-1}\right)$ and nearly equal to atmospheric $\left(11 \mathrm{Gmol} \mathrm{a}^{-1}\right)$ sources, demonstrating that mangroves may be a major contributor in the oceanic Mn cycle [72].

\subsection{Copper ( $\mathrm{Cu}$ ), Zinc ( $\mathrm{Zn})$ and Molybdenum (Mo)}

$\mathrm{Cu}$ is required by plants for chlorophyll and seed production and for many enzymatic activities, and $\mathrm{Zn}$ is essential for good growth and development. Mo is important for $\mathrm{N}$ metabolism; without Mo, plants may be able to utilize inorganic P but cannot convert it to an organic P form that they can use. Mo is also an important cofactor in building 
amino acids and is part of the nitrate reductase and nitrogenase enzymes needed for $\mathrm{NO}_{3}{ }^{-}$ reduction and $\mathrm{N}_{2}$-fixation, respectively. $\mathrm{Cu}, \mathrm{Zn}$, and $\mathrm{Mo}$ are concentrated in mangrove live and dead roots, and to a lesser extent, in leaves [7,8,56-58]. This agrees with Zn uptake and transport in the mangrove, Acanthus ilicifolius, where in Zn-treated cultures [73], most $\mathrm{Zn}$ absorbed by the plant was retained in the roots $(47 \%)$, with less in the stem $(12 \%)$ and leaves $(11 \%)$. Furthermore, treatment with $\mathrm{Zn}$ resulted in increased accumulation of organic solutes, such as free amino acids and soluble sugars, and non-enzymatic antioxidants, such as ascorbate and glutathione [73].

Soil concentrations of all three micronutrients are less than in roots [7,8,56-58]. In $R$. apiculata forests in Thailand [8], total soil pools of Mo and Zn decreased with increasing forest age with the opposite pattern for $\mathrm{Cu}$. In these same forests, the percentage of $\mathrm{Zn}$ and Mo in total living biomass increased from $0.2 \% \mathrm{Zn}$ and $0.6 \%$ Mo in the 3-year-old forest to $0.8 \% \mathrm{Zn}$ and $2 \%$ Mo in the 25-year-old stand [8], indicating increasing accumulation as trees age.

Turnover of $\mathrm{Zn}$ and Mo was most rapid in the 25-year-old forest (Table 5) with a sequence of longer turnover times for $\mathrm{Zn}$ from the most to the least productive forests (Table 5). Cu turnover was not linked to forest productivity, but turnover was longer with increasing forest age (Table 5). In mature Malaysian forests dominated by Bruguiera parviflora [74], soil turnover times for $\mathrm{Cu}$ and $\mathrm{Zn}$ were more rapid at 15 and $13 \mathrm{y}$, respectively. The rate of turnover likely depends on a range of factors in addition to forest age and NPP, including microbial community composition, element species, soil type, root architecture, extent of anoxia, rate of sedimentation, and rate of bioturbation [75]. The abundance of specialized microbes, such as Zn-solubilizing bacteria, will play a role in micronutrient cycling in mangrove soils. For instance, three strains of $\mathrm{Zn}$-solubilizing bacteria were found in Indian soils adjacent to mangroves and in rhizospheres of R. mucronata and $A$. marina [76], where isolated bacterial strains having $\mathrm{Zn}$-solubilizing potential constituted $9.5 \%, 12.5 \%$, and $13.9 \%$ of total bacterial numbers in soil and rhizospheres of $A$. marina and R. mucronata, respectively. These strains exhibited significant release of $\mathrm{Zn}$ as well as acids, and were identified as Pseudomonas aeruginosa [76], demonstrating that specialized bacterial groups exist in mangrove soils and roots systems to facilitate the $\mathrm{Zn}$ cycle.

Mangrove requirements and limitation of $\mathrm{Cu}, \mathrm{Zn}$ and Mo have been studied under experimental conditions $[77,78]$. The relationships of $\mathrm{Zn}$ and $\mathrm{Cu}$ in Avicennia marina were examined and $\mathrm{Cu}$ was accumulated in roots at low soil concentrations, but at concentrations of $200 \mu \mathrm{g} \mathrm{g}^{-1}$ and higher, there was no further $\mathrm{Cu}$ uptake by roots [77]. Seedling height decreased when tissue concentrations were at $100 \mathrm{\mu g} \mathrm{g}^{-1}$. Zn uptake was rapid and was accumulated linearly in roots and translocation to leaves exhibited a dose-dependent relationship with both root and soil concentrations. Significant reductions in seedling height, leaf number, biomass and root growth inhibition were found at high $\mathrm{Zn}$ soil concentrations $\left(500 \mu \mathrm{g} \mathrm{g}^{-1}\right)$. These results of toxicity and growth reductions are not surprising given that the solid-phase $\mathrm{Cu}$ and $\mathrm{Zn}$ concentrations used in this study were much greater than those normally measured in most mangrove soils [1,8,56,65]; dissolved porewater concentrations of both elements are much lower in natural soils, normally within the $\mathrm{nM}$ to $\mu \mathrm{M}$ range $[1,8,65]$. R. apiculata, B. gymnorrhiza, A. marina, Xylocarpus moluccensis, and Ceriops tagal were grown from seedling to sapling stage in mesocosm experiments supplied with increasing amounts of dissolved $\mathrm{Cu}, \mathrm{Zn}$, and Mo at concentrations normally measured in mangrove interstitial waters [78]. Zn and Mo were not limiting for any of the five species, but X. moluccensis growth declined with increasing Mo supply, reflecting lower tolerance and greater toxicity. $\mathrm{Cu}$ was limiting for mangrove growth with rates of stem extension and biomass increasing linearly in R. apiculata, B. gymnorrhiza, A. marina, and C. tagal with increasing rates of $\mathrm{Cu}$ supply, whereas $X$. moluccensis growth best fit Gaussian curves with maximal growth at mid-level $\mathrm{Cu}$ supply with toxicity evident at the highest supply rate [78]. Most $\mathrm{Cu}$ was stored in roots and leaves.

Although there are few data, it appears that depending on species, mangrove growth increases with increasing concentrations of these elements within a narrow window equat- 
ing to natural concentrations in porewater. At high concentrations, dissolved $\mathrm{Cu}, \mathrm{Zn}$ and Mo become toxic, underscoring the fact that these elements are only required in $\mathrm{nM}$ to $\mu \mathrm{M}$ concentrations.

Dissolved Mo uptake by mangroves and their soils appears to be great enough to alter the normally conservative behavior of Mo in estuarine waters [79]. In the Hooghly and Mandovi estuaries in India, dissolved Mo behavior shows net removal from the estuarine waters at lower salinity ranges in proximity to the largest area of mangrove forests. Several factors can contribute to the observed loss of Mo in these two estuaries: (1) enhanced complexation of Mo with organic matter in the water-column at low salinity, (2) development of anoxic conditions in sediments, and (3) uptake from the water by reducing soils and mangrove roots [79]. The reductive removal of Mo is unlikely as other more redox-sensitive elements such as rhenium behave conservatively in estuaries [80]. Thus, Mo removal is more likely the result of selective incorporation into Fe-Mn oxyhydroxides in soil or utilization by microbes or uptake by roots, or both. These results are similar to those found in the Narmada and Tapi estuaries draining into the Arabian Sea [81] showing that Mo removal is not isolated to the Hooghly and Mandovi systems.

These results may have implications for the global ocean Mo budget [79-81]. The global riverine Mo flux of $2.4 \times 10^{8} \mathrm{~mol} \mathrm{a}^{-1}$ increases to $2.6 \times 10^{8} \mathrm{~mol} \mathrm{a}^{-1}$ once Mo flux from low temperature hydrothermal weathering is included. The estimated global oceanic Mo sink is $\approx 0.1 \times 10^{8} \mathrm{~mol} \mathrm{a}^{-1}$ in anoxic sediments and $\approx 0.4 \times 10^{8} \mathrm{~mol} \mathrm{a}^{-1}$ in continental shelf sediments [82]. Extrapolating to the entire Ganga-Brahmaputra estuary, and considering that the mangrove area within the system is $\approx 1.8 \times 10^{10} \mathrm{~m}^{2}$, the Mo sequestration rate is within the range of $0.2-1.7 \mathrm{mmol} \mathrm{m}^{-2} \mathrm{a}^{-1}$ [79]. Assuming that these results are applicable to mangroves globally, the global Mo removal rate by mangrove estuaries is $0.4-3.1 \times 10^{8} \mathrm{~mol} \mathrm{a}^{-1}$, which corresponds to $15-120 \%$ of Mo supply. This range underscores the importance of mangroves in the oceanic Mo budget, indicating that tropical mangrove estuaries are an important sink for Mo and may account for the current 'missing sink' of Mo in the global ocean budget [82]. Furthermore, recent findings suggest that tropical terrestrial forests, perhaps including tropical mangrove forests, receive significant solid-phase Mo from natural atmospheric deposition which is maximal in tropical latitudes [83].

\subsection{Nickel (Ni) and Cobalt (Co)}

$\mathrm{Ni}$ is a component of some plant enzymes, notably urease, which metabolizes urea $\mathrm{N}$ into useable ammonia within the plant; it is also involved in disease tolerance. Co is an essential component of several enzymes and co-enzymes, probably participates in chlorophyll b formation, and has been shown to affect plant growth and metabolism. Co also alters the structure and number of chloroplasts per unit area of leaf. Co and $\mathrm{Ni}$ cycling in mangroves are poorly understood, with only one published study of $\mathrm{Ni}$ cycling [84]. The cycling of Ni in mangrove soils (Figure 7) is a series of redox reactions involving the $\mathrm{Fe}, \mathrm{S}$, and $\mathrm{C}$ cycles partially regulated by $\mathrm{Fe}^{-}$and $\mathrm{SO}_{4}{ }^{3-}$ reducing bacteria. Both $\mathrm{Ni}$ and $\mathrm{Co}$ are stored primarily in live and dead roots, to a greater extent than other micronutrients $[8,57,85]$. This selective storage is likely the result of efficient adsorption of Co to Fe and Mn oxyhydroxides which is an important pathway for Co immobilization under oxic conditions [71]; subsequently, Co is released from the reductive dissolution of Fe and Mn oxyhydroxides. Co mobility is controlled mostly by the redox reactions with Mn oxides, being tightly coupled to Mn possibly because $\mathrm{CoS}_{2}$ is more soluble than sulfides of other trace metals, including Fe [71]. In the $R$. apiculata forests of different age and productivity in southern Thailand [65], porewater concentrations of Co were uniformly low (28-60 nM) among the forests, but porewater Ni concentrations were greater with decreasing NPP, from $85 \mathrm{nM}$ in the most productive stand to $311 \mathrm{nM}$ to the least productive forest [65]. Mean standing amounts of solid-phase Co increased from 26.8 to 41.4 to $48.2 \mathrm{~kg} \mathrm{ha}^{-1}$ in the soils from the most productive to the least productive forests [8]; solid-phase Ni showed no pattern along the productivity gradient but was least abundant 
$\left(49.7 \mathrm{~kg} \mathrm{ha}^{-1}\right)$ in the most productive stand [8]. Solute release across the soil-water interface was rapid for $\mathrm{Ni}\left(1500-6400 \mathrm{nmol} \mathrm{m}^{-2} \mathrm{~h}^{-1}\right)$, indicating a rapid rate of solubilization; Co release was not detected, suggesting immobilization [8]. Microcosm experiments with Brazilian mangrove soils indicated enhancement of Co diffusion into the upper $\mathrm{cm}$ of soil due to bioturbation and retention into the rhizosphere [86]. Both Ni and Co show low translocation factors in leaves and low bioconcentration factors in benthic organisms [87,88]. Ni transport from senescent leaves in central Red Sea mangroves into surface soils was low, averaging $0.003 \mathrm{~g} \mathrm{~m}^{-2} \mathrm{a}^{-1}$, nearly identical to Mo export $\left(0.004 \mathrm{~g} \mathrm{~m}^{-2} \mathrm{a}^{-1}\right)$. While Ni and Co are required by mangroves, they do not appear to be readily cycled.

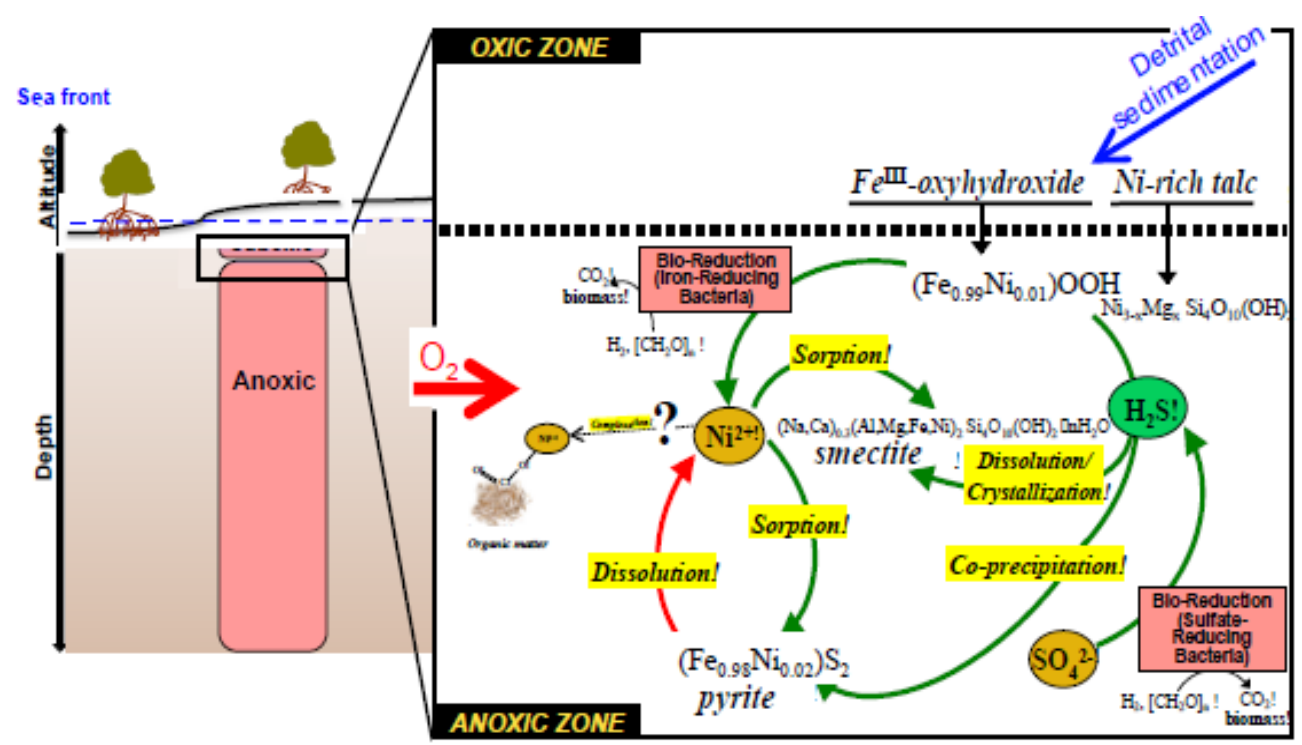

Figure 7. Ni cycling in mangrove soils focusing on the oxic-anoxic interface. In the anoxic zone, Ni-bearing Fe oxyhydroxides (blue arow) derived from detrital sedimentation undergo reduction reactions (green arrows) resulting the $\mathrm{Ni}$ incorporation into pyrite and sorption onto pyrite. Feoxyhydroxides may be reduced by Fe-reducing bacteria or by free sulfides produced by sulfatereducing bacteria. Ni-rich clays such as Ni-rich talc are suspected to dissolved under reduced conditions, releasing $\mathrm{Ni}$ to porewater, possibly via $\mathrm{Ni}$ complexation by $\mathrm{HS}^{-}$. In contrast, oxygenation (red arrow) leads to oxidative dissolution of Ni-bearing pyrite which releases $\mathrm{Ni}^{2+}$ that may be re-adsorbed onto $\mathrm{FeS}_{2}$. Source: [84]. Reproduced with permission from Elsevier.

\section{Discussion}

\subsection{An Emerging Picture}

As changes in nitrogen and phosphorus availability and their relative abundance may have controlled the size and activity of the biosphere through geologic time [89], most biogeochemical research has naturally focused on their role in terrestrial and aquatic ecosystems, including mangroves $[7,13,14]$. Cycling of the other macronutrients $(\mathrm{S}, \mathrm{Mg}$, $\mathrm{Ca}$, and $\mathrm{K}$ ) is less well understood, although their participation in plant ecophysiological processes, such as tolerating salt and anoxia and maintaining osmotic balance, is crucial for mangrove survival in waterlogged, saline environments $[1,3,6]$.

A picture is now emerging in which the cycling of macro- and micronutrients in mangroves is often interlinked, and that nutrient cycles are to a considerable degree reliant on and coupled to several geochemical transformation processes, such as redox oscillations and trace element speciation. Nutrient transformation reactions are very efficient due to several conservation and retention strategies which allow the uptake of labile solutes at rates necessary to sustain the high rates of mangrove productivity. The nutrient situation is considerably different in mangroves significantly impacted by anthropogenic activities, such as eutrophication and metal pollution, excess sedimentation, and global environmental change. As reviewed by Reis et al. [90], mangroves subjected to nutrient 
enrichment show strong net import of DIN and DON with more rapid rates of soil ammonification and $\mathrm{N}_{2} \mathrm{O}$ fluxes to the atmosphere, compared to relatively pristine mangroves. However, benthic $\mathrm{N}_{2}$-fixation is lower in enriched (mean: 2; range: $0-8 \mathrm{mg} \mathrm{N} \mathrm{m}^{-2} \mathrm{~d}^{-1}$ ) than in natural (mean: 7; range: $0-69 \mathrm{mg} \mathrm{N} \mathrm{m}^{-2} \mathrm{~d}^{-1}$ ) soils. When mangroves are contaminated by excess trace element concentrations, they bioaccumulate in tree components, especially leaves and roots, but induce toxicity when at concentrations above the nano- to low micro-molar amounts in porewater of unpolluted mangrove soils $[3,6,41,77]$. Other anthropogenic problems, especially those related to climate change, such as sea-level rise and rising temperatures, similarly affect nutrient dynamics in mangrove ecosystems [91].

\subsection{The Overlooked Role of Micronutrients}

Mangroves can be limited by $\mathrm{N}$ and $\mathrm{P}$, but also by the micronutrients $\mathrm{Fe}, \mathrm{Cu}$ and, to a limited extent, $\mathrm{Zn}$ and Mo, under conditions of low porewater availability. Limited availability is most often caused by sorption and retention of dissolved metals onto solidphase minerals such as Fe oxyhydroxides, clays, and sulfide minerals. Trace nutrients can also be lost from mangrove forests by porewater seepage and groundwater pumping to adjacent tidal waterways $[92,93]$. Thus, they are normally found only in exceedingly low concentrations in mangrove porewaters. Nutrient availability is also controlled partly by the activities of specialized fungi and solubilizing bacteria.

Understanding the vital role of trace elements in mangrove ecosystems is still in its infancy, which is somewhat surprising given that the role of trace metals in limiting the growth and productivity of other marine autotrophs has been known for several decades. Coastal and oceanic phytoplankton require trace metals such as $\mathrm{Fe}, \mathrm{Ni}, \mathrm{Cu}, \mathrm{Zn}, \mathrm{Mn}, \mathrm{Co}$, and $\mathrm{Cd}$ for their growth [94,95]. Of these, $\mathrm{Fe}$ is most limiting to phytoplankton growth and has the greatest effect on algal species diversity; it also limits $\mathrm{N}_{2}$-fixation [96]. Other trace elements $(\mathrm{Zn}, \mathrm{Co}, \mathrm{Cu}, \mathrm{Mn})$ have lesser effects on productivity, but may exert an important influence on species composition because of species-specific differences in trace metal requirements [96]. Molybdenum plays an important role in regulating $\mathrm{N}_{2}$-fixation in $\mathrm{N}$-deleted waters [97].

Seagrasses have similar requirements for macro- and micronutrients, often being limited by N, P and Fe [98-100]. The mechanism for Fe limitation is both direct and indirect, with uptake of soluble Fe via rhizomes and enhanced plant growth indirectly by the suppression of sulfate reduction and sulfide production, thus removing sulfide stress and increasing Fe and P availability due to reduced precipitation of Fe sulfides. Fe is especially limiting for seagrasses in carbonate environments [98-100].

Micronutrients such as $\mathrm{Fe}, \mathrm{Mn}$ and Mo play an important role in $\mathrm{N}$ metabolism and photosynthesis via organic matter diagenesis. Fe is involved in nitrification, denitrification and anammox and $\mathrm{Mo}$ is involved in $\mathrm{NO}_{3}{ }^{-}$reduction and $\mathrm{N}_{2}$-fixation. $\mathrm{Zn}$ addition to plants results in increased accumulation of free amino acids, sugars, and antioxidants. Furthermore, $\mathrm{P}$ availability may be coupled to Fe-S redox oscillations during the drying and flooding of soils. Soil Mg, K, Mn, Zn and Ni pool sizes decrease as mangrove productivity increases suggesting increasing transformation and uptake, and more rapid turnover of soil nutrient pools, than in less productive forests; these elements are vital for plant growth and productivity.

Dissolved Mn and Mo exported from mangroves may be major contributors in their ocean cycles. Globally, mangroves deliver 7.4-12.1 $\mathrm{Gmol} \mathrm{Mn} \mathrm{a}^{-1}$ to the ocean, greater than global riverine flux and equal to atmospheric inputs. The global Mo removal rate by mangrove estuaries is $0.4-3.1 \times 10^{8} \mathrm{~mol} \mathrm{a}^{-1}$ which corresponds to $15-120 \%$ of Mo supply to the oceanic Mo budget, indicating that estuaries associated with mangroves are an important sink for Mo which may account for the current 'missing sink' in the global ocean Mo budget. 


\subsection{Perspectives for Further Research}

Some perspectives for future research are offered. First, globally, nutrient cycling has been measured mostly in Australia, Brazil, Florida, Belize, Malaysia, Thailand, and India; data are lacking for most countries in Africa, Oceania, Asia, and the Americas. Furthermore, most of these studies involved sampling of only a handful of sites and usually only during one season, making it difficult to understand the importance of spatial and temporal variations in nutrient fluxes. Second, information is lacking from mangrove soils deeper than $50 \mathrm{~cm}$. It is likely that nutrients are transformed and recycled in deep deposits, as microbial carbon decomposition has been measured to soil depth of $1 \mathrm{~m}$ and found to be rapid, especially in relation in deep roots and biogenic structures [35]. Third, wet and dry deposition from the atmosphere into mangrove forests may be significant inputs for most elements, as indicated by the large atmospheric dry P deposition in the Sundarbans mangroves (Figure 4). Tropical terrestrial forests receive relatively large deposits of N, P, Fe, $\mathrm{Mo}$, and $\mathrm{S}$ and trace elements to the forest floor via throughfall [101,102]. These aerosols are derived mainly from biomass burning, sea salts, industrial pollution, and dust. Within the Great Barrier Reef region, collected aerosols contained significant amounts of $\mathrm{Fe}, \mathrm{Cd}, \mathrm{Co}, \mathrm{Cu}$, $\mathrm{Mo}, \mathrm{Mn}, \mathrm{Pb}, \mathrm{V}$ and $\mathrm{Zn}$, undoubtedly depositing on the extensive mangrove forests living along the coast [103]. Fourth, better understanding of how nutrients interact with each other is needed to clarify element cycles and their impacts on mangrove nutrition. Fifth, studies are needed to integrate and possibly find additional links between biogeochemical and geochemical processes as elements other than $\mathrm{Fe}, \mathrm{Mo}, \mathrm{S}$, and $\mathrm{Mn}$ may be important for $\mathrm{N}$ and $\mathrm{P}$ transformations and cycles. Sixth, quantification of faunal contributions and utilization of nutrients is needed, especially crabs, epiphytes, cyanobacteria, plankton, and fish. Seventh, direct groundwater inputs, including porewater seepage and inputs from upstream and marine sources are quantitatively important but more mangroves in disparate geomorphological settings and tidal regimes need to be studied as these inputs are likely to vary greatly among locations. Finally, more data are required to construct mass balances and cycling models for $\mathrm{Mg}, \mathrm{Ca}, \mathrm{K}, \mathrm{Si}, \mathrm{Mn}, \mathrm{Cu}, \mathrm{Zu}$, and Mo to better understand their roles in mangrove productivity, ecosystem dynamics and coastal processes.

\section{Conclusions}

Several conclusions concerning the present state of our knowledge of mangrove nutrient cycles can be drawn:

1. Nutrients are stored primarily in the soil pool but also in leaves and roots, in the former where nutrients are utilized in photosynthesis and in the latter where they are initially taken up from soils, respectively. Nutrient stocks in wood are low. The C:N:P stoichiometry of burial in mangrove soils is 95:7:1, which is considerably less than in mangrove matter (C:N:P = 3405:23:1) indicating preferential burial of $\mathrm{N}$ and $\mathrm{P}$ in relation to $\mathrm{C}$.

2. Depending on growth stage, species, and environmental conditions, mangrove growth can be limited not only by $\mathrm{N}$ and $\mathrm{P}$, but also by low interstitial water concentrations of $\mathrm{Fe}, \mathrm{Cu}, \mathrm{Zn}$ and Mo.

3. Only the $\mathrm{N}$ cycle is well understood, with little $\mathrm{N}$ export and high $\mathrm{N}$ retention and conservation; $\mathrm{NH}_{4}{ }^{+}$immobilization into the soil pool is the largest $\mathrm{N}$ transformation process.

4. $\mathrm{Fe}, \mathrm{Mn}, \mathrm{S}$ and Mo affect $\mathrm{N}$ metabolism and photosynthesis via organic matter diagenesis and $\mathrm{P}$ availability may be coupled to Fe-S redox oscillations during drying and flooding of soils. Fe is involved in nitrification, denitrification and anammox and Mo is involved in $\mathrm{NO}_{3}{ }^{-}$reduction and $\mathrm{N}_{2}$-fixation.

5. Zn addition to plants results in increased accumulation of free amino acids, sugars, and antioxidants.

6. Soil Mg, K, Mn, Zn and Ni pool sizes decrease as mangrove NP increases, suggesting increasing transformation and uptake, and more rapid turnover, than in less productive forests. Solid-phase Co shows the opposite pattern. 
7. The exchange of mangrove macro- and micronutrients with adjacent coastal waters have major impacts on nutrient cycles in the tropical coastal ocean. This includes not only $\mathrm{N}$ and $\mathrm{P}$ exchanges, but also $\mathrm{Mn}$ and Mo fluxes.

Funding: This research received no external funding.

Institutional Review Board Statement: Not applicable.

Informed Consent Statement: Not applicable.

Data Availability Statement: All data used in this manuscript has been previously published in the papers cited in the References section. Data in Section 2.1 was taken from the original references cited in [9]. All other original sources are cited in the text, table, and figure legends. Figures 1 and 3 are original but contain no numerical data.

Conflicts of Interest: The author declares no conflict of interest.

\section{References}

1. Alongi, D.M. The Energetics of Mangrove Forests; Springer Science: Dordrecht, The Netherlands, 2009.

2. Twilley, R.R.; Day, J.W., Jr. Mangrove wetlands. In Estuarine Ecology, 2nd ed.; Day, J.W., Jr., Crump, B.C., Kemp, W.M., YañezArancibia, A., Eds.; Wiley-Blackwell: New York, NY, USA, 2013; pp. 165-202.

3. Ball, M.C. Ecophysiology of mangroves. Trees 1988, 2, 129-142. [CrossRef]

4. Bashan, Y.; Holguin, G. Plant growth-promoting bacteria: A potential tool for arid mangrove reforestation. Trees 2002, 16, 159-166. [CrossRef]

5. Shuman, L.M. Mineral nutrition. In Plant-Environment Interactions, 2nd ed.; Wilkinson, R.E., Ed.; Marcel Dekker: New York, NY, USA, 2000; pp. 65-109.

6. Reef, R.; Feller, I.C.; Lovelock, C.E. Nutrition of mangroves. Tree Physiol. 2010, 30, 1148-1160.

7. Alongi, D.M.; Clough, B.F.; Dixon, P.; Tirendi, F. Nutrient partitioning and storage in arid-zone forests of the mangrove Rhizophora stylosa and Avicennia marina. Trees 2003, 17, 51-60. [CrossRef]

8. Li, M.S. Nutrient dynamics of a Futian mangrove forest in Shenzhen, South China. Estuar. Coast. Shelf Sci. 1997, 45, 463-472. [CrossRef]

9. Alongi, D.M. Nitrogen cycling and mass balance in the world's mangrove forests. Nitrogen 2020, 1, 167-189. [CrossRef]

10. Alongi, D.M. The dynamics of benthic nutrient pools and fluxes in tropical mangrove forests. J. Mar. Res. 1996, 54, 123-148. [CrossRef]

11. Zhang, M.; Luo, Y.; Lin, L.; Lin, X.; Hetharua, B.; Zhao, W.; Zhou, M.; Zhan, Q.; Xu, H.; Zheng, T.; et al. Molecular and stable isotope evidence for the occurrence of nitrite-dependent anaerobic methane-oxidizing bacteria in mangrove sediment of Zhangjiang estuary, China. Appl. Microbiol. Biotechnol. 2018, 102, 2441-2454. [CrossRef] [PubMed]

12. Seitzinger, S.; Harrison, J.A.; Böhlke, J.K.; Bouwman, A.F.; Lowrance, R.; Peterson, B.; Tobias, C.; Van Drecht, G. Denitrification across landscapes and waterscapes: A synthesis. Ecol. Appl. 2006, 16, 2064-2090. [CrossRef]

13. Kristensen, E.; Connolly, R.M.; Otero, X.L.; Marchand, C.; Ferreira, T.O.; Rivera-Monroy, V.H. Biogeochemical cycles: Global approaches and perspectives. In Mangrove Ecosystems: A Global Biogeographic Perspective; Rivera-Monroy, V.H., Lee, S.Y., Kristensen, E., Twilley, R.R., Eds.; Springer: Cham, Switzerland, 2017; pp. 163-209.

14. Alongi, D.M.; Boto, K.G.; Robertson, A.I. Nitrogen and phosphorus cycles. In Tropical Mangrove Ecosystems; Robertson, A.I., Alongi, D.M., Eds.; American Geophysical Union: Washington, DC, USA, 1992; pp. 251-292.

15. Singh, G.; Chauhan, R.; Kumar Ranjan, R.; Balakrishna Prasad, M.; Ramanathan, A.L. Phosphorus dynamics in mangrove of India. Curr. Sci. 2015, 108, 1874-1881.

16. Feller, I.C.; Lovelock, C.E.; McKee, K.L. Nutrient addition differentially affects ecological processes of Avicennia germinans in nitrogen versus phosphorus limited mangrove ecosystems. Ecosystems 2007, 10, 347-359. [CrossRef]

17. El-Tarabily, K.A.; Youssef, T. Enhancement of morphological, anatomical, and physiological characteristics of seedlings of the mangrove Avicennia marina inoculated with a native phosphate-solubilizing isolate of Oceanobacillus picturae under greenhouse conditions. Plant Soil 2010, 332, 147-162. [CrossRef]

18. Scharler, U.M.; Ulanowicz, R.E.; Fogel, M.L.; Wooler, M.J.; Jacobson-Meyer, M.E.; Lovelock, C.E.; Feller, I.C.; Frischer, M.; Lee, R.; McKee, K.; et al. Variable nutrient stoichiometry (carbon: Nitrogen: Phosphorus) across trophic levels determines community and ecosystem properties in an oligotrophic mangrove system. Oecologia 2015, 179, 863-876. [CrossRef]

19. Xie, X.; Weng, B.; Cai, B.; Dong, Y.; Yan, C. Effects of arbuscular mycorrhizal inoculation and phosphorus supply on the growth and nutrient uptake of Kandelia obovata (Sheue, Liu \& Yong) seedlings in autoclaved soil. Appl. Soil Ecol. 2014, 75, 162-171.

20. Das, S.; Jana, T.L.; De, T.K. Vertical profile of phosphatase activity in the Sundarbans mangrove forest, North East coast of Bay of Bengal, India. Geomicrobiol. J. 2014, 31, 716-725. [CrossRef]

21. Behera, B.C.; Singdevsachan, S.K.; Mishra, R.R.; Sethi, B.K.; Dutta, S.K.; Thatoi, H.N. Phosphate solubilizing bacteria from mangrove soils of Mahanadi River Delta, Odisha, India. World J. Agric. Res. 2016, 4, 18-23. 
22. Behera, B.C.; Yadav, H.; Singh, S.K.; Mishra, R.R.; Sethi, B.K.; Dutta, S.K.; Thatoi, H.N. Phosphate solubilization and acid phosphatase activity of Serratia sp., isolated from mangrove soil of Mahanadi river delta, Odisha, India. J. Genet. Eng. Biotechnol. 2017, 15, 169-178. [CrossRef]

23. Abhijith, R.; Vennila, A.; Purushothaman, C.S.; Padua, S.; Shilta, M.T.; Mahesh, V. Influence of sediment chemistry on mangrovephosphobacterial relationship. Int. J. Chem. Stud. 2018, 6, 1677-1686.

24. Silva, C.A.R.; Mozeto, A.A.; Ovalle, R.C. Distribution and fluxes as microdetritus of phosphorus in red mangroves, Sepetiba Bay, Brazil. Mangrove Salt Marshes 1998, 2, 37-42. [CrossRef]

25. Ramos e Silva, C.A.; Oliveira, S.R.; Régo, R.D.P.; Mozeto, A.A. Dynamics of phosphorus and nitrogen through litter fall and decomposition in a tropical mangrove forest. Mar. Environ. Res. 2007, 64, 524-534. [CrossRef]

26. Nielsen, T.; Andersen, F.Ø. Phosphorus dynamics during decomposition of mangrove (Rhizophora apiculata) leaves in sediments. J. Exp. Mar. Biol. Ecol. 2003, 293, 73-88. [CrossRef]

27. Ray, R.; Majumder, N.; Das Chowdhury, S.; Jana, T.K. Phosphorus budget of the Sundarbans mangrove ecosystem: Box model approach. Estuar. Coast. 2018, 41, 1036-1049. [CrossRef]

28. Breithaupt, J.L.; Smoak, J.M.; Smith, T.J., III; Sanders, C.J. Temporal variability of carbon and nutrient burial, sediment accretion, and mass accumulation over the past century in a carbonate platform mangrove forest of the Florida Everglades. J. Geophys. Res. Biogeosci. 2014, 119, 2032-2048. [CrossRef]

29. Sanders, C.J.; Santos, I.R.; Maher, D.T.; Breithaupt, J.L.; Smoak, J.M.; Ketterer, M.; Call, M.; Sanders, L.; Eyre, B.D. Examing ${ }^{239+240} \mathrm{Pu},{ }^{210} \mathrm{~Pb}$ and historical events to determine carbon, nitrogen and phosphorus burial in mangrove sediments of Moreton Bay, Australia. J. Environ. Radioact. 2016, 151, 623-629. [CrossRef] [PubMed]

30. Breithaupt, J.L.; Smoak, J.M.; Sanders, C.J.; Troxler, T.G. Spatial variability of organic carbon, $\mathrm{CaCO}_{3}$ and nutrient burial rates spanning a mangrove productivity gradient in the coastal Everglades. Ecosystems 2019, 22, 844-858. [CrossRef]

31. Pérez, A.; Machado, W.; Gutierrez, D.; Smoak, J.M.; Breithaupt, J.L.; Saldarriaga, M.S.; Sanders, L.; Marotta, H.; Sanders, C.J. Carbon and nutrient accumulation in mangrove sediments affected by multiple environmental changes. J. Soil. Sediments 2020, 20, 2504-2509. [CrossRef]

32. Pérez, A.; Machado, W.; Gutierrez, D.; Saldarriaga, M.S.; Sanders, C.J. Shrimp farming influence on carbon and nutrient accumulation within Peruvian mangrove sediments. Estuar. Coast. Shelf Sci. 2020, 243, 106879. [CrossRef]

33. Matos, C.R.L.; Berrêdo, J.F.; Machado, W.; Sanders, C.J.; Metzger, E.; Cohen, M.C.L. Carbon and nutrient accumulation in tropical mangrove creeks, Amazon region. Mar. Geol. 2020, 429, 106317. [CrossRef]

34. Saderne, V.; Cusack, M.; Serrano, O.; Almahasheer, H.; Krishnakumar, P.K.; Rabaoui, L.; Qurban, M.A.; Duarte, C.M. Role of vegetated coastal ecosystems as nitrogen and phosphorus filters and sinks in the coasts of Saudi Arabia. Environ. Res. Lett. 2020, 15, 034058. [CrossRef]

35. Alongi, D.M. Carbon cycling in the world's mangrove ecosystems revisited: Significance of non-steady state diagenesis and subsurface linkages between the forest floor and the coastal ocean. Forests 2020, 11, 977. [CrossRef]

36. Gong, W.-K.; Ong, J.-E. Plant biomass and nutrient flux in a managed mangrove forest in Malaysia. Estuar. Coast. Shelf Sci. 1990, 31, 519-530. [CrossRef]

37. Alongi, D.M.; Wattayakorn, G.; Tirendi, F.; Dixon, P. Nutrient capital in different aged forests of the mangrove Rhizophora apiculata. Bot. Mar. 2004, 47, 116-124. [CrossRef]

38. Burgin, A.J.; Yang, W.H.; Hamilton, S.K.; Silver, W.L. Beyond carbon and nitrogen: How the microbial energy economy couples elemental cycles in diverse ecosystems. Front. Ecol. Environ. 2011, 9, 44-52. [CrossRef]

39. Pan, F.; Liu, H.; Guo, Z.; Li, Z.; Wang, B.; Cai, Y.; Gao, A. Effects of tide and season changes on the iron-sulfur-phosphorus biogeochemistry in sediment porewater of a mangrove coast. J. Hydrol. 2019, 568, 686-702. [CrossRef]

40. Du, J.; Liu, J.; Lu, H.; Hansell, D.; Zhang, Q.; Wang, W.; Yan, C. Effect of external phosphate addition on solid-phase iron distribution and iron accumulation in mangrove Kandelia obovata (S.L.). Environ. Sci. Pollut. Res. 2015, 22, 13506-13513. [CrossRef]

41. Dai, M.; Liu, J.; Liu, W.; Lu, H.; Jia, H.; Hong, H.; Yan, C. Phosphorus effects on radial oxygen loss, root porosity and iron plaque in two mangrove seedlings under cadmium stress. Mar. Pollut. Bull. 2017, 119, 262-269. [CrossRef] [PubMed]

42. Kristensen, E.; Alongi, D.M. Control by fiddler crabs (Uca vocans) and plant roots (Avicennia marina) on carbon, iron, and sulfur biogeochemistry in mangrove sediment. Limnol. Oceanogr. 2006, 51, 1557-1571. [CrossRef]

43. Hinokidani, K.; Nakanishi, Y. Dissolved iron elution from mangrove ecosystem associated with polyphenols and a herbivorous snail. Ecol. Evol. 2019, 9, 672-6784. [CrossRef]

44. Attri, K.; Kerkar, S.; Loka Bharathi, P.A. Ambient iron concentration regulates the sulfur reducing activity in the mangrove swamps of Diwar, Goa, India. Estuar. Coast. Shelf Sci. 2011, 95, 156-164. [CrossRef]

45. Arrivabene, H.P.; Campos, C.Q.; Souza, I.C.; Wunderlin, D.A.; Milanez, C.R.D.; Machado, S.R. Differential bioaccumulation and translocation patterns in three mangrove plants experimentally exposed to iron. Consequences for environmental sensing Environ. Pollut. 2016, 215, 302-313. [CrossRef] [PubMed]

46. Krishnan, K.P.; Loka Bharathi, P.A. Organic carbon and iron modulate nitrification rates in mangrove swamps of Goa, south west coast of India. Estaur. Coast. Shelf Sci. 2009, 84, 419-426. [CrossRef]

47. Fernandes, S.O.; Gonsalves, M.-J.; Michotey, V.D.; Bonin, P.C.; Loka Bharathi, P.A. Denitrification activity is closely linked to the total ambient Fe concentrations in mangrove sediments of Goa, India. Estuar. Coast. Shelf Sci. 2013, 131, 64-74. [CrossRef] 
48. Guan, Q.S.; Cao, W.Z.; Wu, G.J.; Wang, F.F.; Jiang, C.; Tao, Y.R.; Gao, Y. Nitrogen loss through anaerobic ammonium oxidation coupled with iron reduction in a mangrove wetland. Eur. J. Soil Sci. 2018, 69, 732-741. [CrossRef]

49. Guan, Q.; Zhang, Y.; Tao, Y.; Chang, C.-T.; Cao, W. Graphene functions as a conductive bridge to promote anaerobic ammonium oxidation coupled with iron reduction in mangrove sediment slurries. Geoderma 2019, 352, 181-184. [CrossRef]

50. Zheng, Y.; Hou, L.; Zhang, Z.; Chen, F.; Gao, D.; Yin, G.; Han, P.; Dong, H.; Liang, X.; Yang, Y. Anaerobic ammonium oxidation (anammox) bacterial diversity, abundance, and activity in sediments in the Indus Estuary. Estuar. Coast. Shelf Sci. 2020, 243, 106925. [CrossRef]

51. Raven, M.R.; Fike, D.A.; Gomes, M.L.; Webb, S.M. Chemical and isotopic evidence for organic matter sulfurization in redox gradients around mangrove roots. Front. Earth Sci. 2019, 7, 98. [CrossRef]

52. Crémiere, A.; Strauss, H.; Sebilo, M.; Hong, W.-L.; Gros, O.; Schmidt, S.; Tocny, J.; Henry, F.; Gontharet, S.; Lavenman, A.M. Sulfur diagenesis under rapid accumulation of organic-rich sediments in a marine mangrove from Guadeloupe (French West Indies). Chem. Geol. 2017, 454, 67-79. [CrossRef]

53. Alongi, D.M. Dissolved iron supply limits early growth of estuarine mangroves. Ecology 2010, 91, 3229-3241. [CrossRef]

54. Almahasheer, H.; Duarte, C.M.; Irigoien, X. Nutrient limitation in Central Red Sea mangroves. Front. Mar. Sci. $2016,3,271$. [CrossRef]

55. Cuadros, J.; Andrade, G.; Ferreira, T.O.; de Moya Partiti, C.S.; Cohen, R.; Vidal-Torrado, P. The mangrove reactor: Fast clay transformation and potassium sink. Appl. Clay Sci. 2017, 140, 50-58. [CrossRef]

56. Mantiquilla, J.A.; Salmasan, S.F.D.; Obelidhon, M.K.A.; Abad, R.G. Nutrient status of Nipa (Nypa fruticans Wurmb.) in selected areas of Mindanao, the Philippines. Banwa B 2019, 14, art012.

57. Jayasekera, R. Chemical composition of the mangrove, Rhizophora mangle L. J. Plant. Physiol. 1991, 138, 119-121. [CrossRef]

58. Hossain, M.; Othman, S.; Bujang, J.S.; Kusman, M. Macronutrients content in different parts of seedling, sapling and tree of Bruguiera parviflora of Kuala Selangor Nature Park Mangrove Forest in Malaysia. Khulna Univ. Stud. 2003, 5, 15-20.

59. Medina, E.; Fernandez, W.; Barboza, F. Element uptake, accumulation, and resorption in leaves of mangrove species with different mechanisms of salt regulation. Web Ecol. 2015, 15, 3-13. [CrossRef]

60. Nasrin, S.; Hossain, M.; Rahman, M.M. Adaptive responses to salinity: Nutrient resorption efficiency of Sonneratia apetala (Buch.-Ham.) along the salinity gradient in the Sundarbans of Bangladesh. Wetl. Ecol. Manag. 2019, 27, 343-351. [CrossRef]

61. Nandy, P.; Das, S.; Ghose, M.; Spooner-Hart, R. Effects of salinity on photosynthesis, leaf anatomy, ion accumulation and photosynthetic nitrogen use efficiency in five Indian mangroves. Wetl. Ecol. Manag. 2007, 15, 347-357. [CrossRef]

62. Ball, M.C.; Chow, W.S.; Anderson, J.M. Salinity-induced potassium deficiency causes loss of functional photosystem II in leaves of the grey mangrove, Avicennia marina, through depletion of the atrazine-binding polypeptide. Aust J. Plant. Physiol. 1987, 14, 351-361. [CrossRef]

63. Osman, H.E.; AboHassan, A.A. Effect of NPK fertilization on growth and dry matter accumulation in mangrove [Avicennia marina (Forssk) vierh] grown in western Saudi Arabia. Meteorol. Environ. Arid Land Agric. Sci. 2010, 21, 57-70. [CrossRef]

64. Yates, E.J.; Ashwath, N.; Midmore, D.J. Responses to nitrogen, phosphorus, potassium and sodium chloride by three mangrove species in pot culture. Trees 2002, 16, 120-125. [CrossRef]

65. Alongi, D.M.; Wattayakorn, G.; Boyle, S.; Tirendi, F.; Payn, C.; Dixon, P. Influence of roots and climate on mineral and trace element storage and flux in tropical mangrove soils. Biogeochemistry 2004, 69, 105-123. [CrossRef]

66. Ray, R.; Mandal, S.K.; González, A.G.; Pokrovsky, O.S.; Jana, T.K. Storage and recycling of major and trace elements in mangroves. Sci. Total Environ. 2021, 780, 146379. [CrossRef]

67. Sahebi, M.; Hanafi, M.M.; Akmar, A.S.N.; Rafi, M.Y.; Azizi, P.; Idris, A.S. Serine-rich protein is a novel positive regulator for silicon accumulation in mangrove. Gene 2015, 556, 170-181. [CrossRef]

68. Zhang, Q.; Liu, J.; Lu, H.; Zhao, S.; Wang, W.; Du, J.; Yan, C. Effects of silicon on growth, root anatomy, radial oxygen loss (ROL) and Fe/N plaque of Aegiceras corniculatum (L.) Blanco seedlings exposed to cadmium. Environ. Nanotechnol. Monit. Manag. 2015, 4, 6-11. [CrossRef]

69. Alongi, D.M.; Ramanathan, A.L.; Kannan, L.; Tirendi, F.; Trott, L.A.; Bala Krishna Prasad, M. Influence of human-induced disturbance on benthic microbial metabolism in the Pichavaram mangroves, Vellar-Coleroon estuarine complex, India. Mar. Biol. 2005, 147, 1033-1044. [CrossRef]

70. Alongi, D.M.; Pfitzner, J.; Trott, L.A.; Tirendi, F.; Dixon, P.; Klumpp, D.W. Rapid sediment accumulation and microbial mineralization in forests of the mangrove Kandelia candel in the Jiulongjiang estuary, China. Estuar. Coast. Shelf Sci. 2005, 63, 605-618. [CrossRef]

71. Pan, F.; Liu, H.; Guo, Z.; Cai, Y.; Fu, Y.; Wu, J.; Wang, B.; Gao, A. Metal/metalloid and phosphorus characteristics in porewater associated with manganese geochemistry: A case study in the Jiulong River estuary, China. Environ. Pollut. 2019, $255,113134$. [CrossRef]

72. Holloway, C.J.; Santos, I.R.; Tait, D.R.; Sanders, C.J.; Rose, A.L.; Schnetger, B.; Brumsack, H.-J.; Macklin, P.A.; Sippo, J.Z.; Maher, D.T. Manganese and iron release from mangrove porewaters: A significant component of oceanic budgets? Mar. Chem. 2016, 184, 43-52. [CrossRef]

73. Shackira, A.M.; Puthur, J.T.; Salim, E.N. Acanthus ilicifolius L. a promising candidate for phytostabilization of zinc. Environ. Monit. Assess. 2017, 189, 282. [CrossRef] 
74. Hossain, M.; Othman, S.; Kusnan, M.; Bujang, J.S. Biological cycling of micro-nutrients (Cu, Fe and Zn) in Bruguiera parviflora dominated mangrove forest at Kuala Selangor Nature Park, Malaysia. Malays. Appl. Biol. 2008, 37, $63-68$.

75. De Araújo, J.M.C., Jr.; Ferreira, T.O.; Suarez-Abelenda, M.; Nóbrega, G.N.; Albuquerque, A.G.B.M.; de Bezerra, A.C.; Otero, X.L. The role of bioturbation by Ucides cordatus crab in the fractionation and bioavailability of trace metals in tropical semiarid mangroves. Mar. Pollut. 2016, 111, 194-202. [CrossRef]

76. Jerlin, B.; Sharmila, S.; Kathiresan, K.; Kayalvizhi, K. Zinc solubilizing bacteria from rhizospheric soil of mangroves. Int. J. Microbiol. Biotechnol. 2017, 2, 148-155.

77. MacFarlane, G.R.; Burchett, M.D. Toxicity, growth and accumulation relationships of copper, lead and zinc in the grey mangrove Avicennia marina (Forsk.) Vierh. Mar. Environ. Res. 2002, 54, 65-84. [CrossRef]

78. Alongi, D.M. Micronutrients and mangroves: Experimental evidence for copper limitation. Limnol. Oceanogr. 2017, 62, 2759-2772. [CrossRef]

79. Rahaman, W.; Singh, S.K.; Raghav, S. Dissolved Mo and U in rivers and estuaries of India: Implication to geochemistry of redox sensitive elements and their marine budgets. Chem. Geol. 2010, 278, 160-172. [CrossRef]

80. Ravizza, G.; Turekian, K.K.; Hay, B.J. The geochemistry of rhenium and osmium in recent sediments from the Black Sea. Geochim. Cosmochim. Acta 1991, 55, 3741-3752. [CrossRef]

81. Rahaman, W.; Goswami, V.; Singh, S.K.; Rai, V.K. Molybdenum isotopes in two Indian estuaries: Mixing characteristics and input to oceans. Geochim. Cosmochim. Acta 2014, 141, 407-422. [CrossRef]

82. McManus, J.; Berelson, W.M.; Severmann, S.; Poulson, R.L.; Hammond, D.E.; Klinkhammer, G.P.; Holm, C. Molybdenium and uranium geochemistry in continental margin sediments: Paleoproxy potential. Geochim. Cosmochim. Acta 2006, 70, 4643-4662. [CrossRef]

83. Wong, M.Y.; Mahowald, N.M.; Marino, R.; Williams, E.R.; Chellam, S.; Howarth, R.W. Natural atmospheric deposition of molybdenium: A global model and implications for tropical forests. Biogeochemistry 2020, 149, 159-174. [CrossRef]

84. Noël, V.; Morin, G.; Juillot, F.; Marchand, C.; Brest, J.; Bargar, J.R.; Muñoz, M.; Marakovic, G.; Ardo, S.; Brown, G.E., Jr. Ni cycling in mangrove sediments in New Caledonia. Geochim. Cosmochim. Acta 2015, 169, 82-98. [CrossRef]

85. Marchand, C.; Fernandez, J.-M.; Moreton, B. Trace metal geochemistry in mangrove sediments and their transfer to mangrove plants (New Caledonia). Sci. Total Environ. 2016, 562, 216-227. [CrossRef]

86. Suzuki, K.N.; Machado, E.C.; Machado, W.; Bellido, A.V.; Bellido, L.F.; Osso, J.A., Jr.; Lopes, R.T. Selenium, chromium and cobalt diffusion into mangrove sediments: Radiotracer experiment evidence of coupled effects of bioturbation and rhizosphere. Water Air Soil Pollut. 2012, 223, 3887-3892. [CrossRef]

87. Almahasheer, H.; Serrano, O.; Duarte, C.M.; Irigoien, X. Remobilization of heavy metals by mangrove leaves. Front. Mar. Sci. 2018, 5, 484. [CrossRef]

88. Thanh-Nho, N.; Marchand, C.; Strady, E.; Huu-Phat, N.; Nhu-Trang, T.-T. Bioaccumulation of some trace elements in tropical mangrove plants and snails (Can Gio, Vietnam). Environ. Pollut. 2019, 248, 635-645. [CrossRef] [PubMed]

89. Schlesinger, W.H.; Bernhardt, E.S. Biogeochemistry: An Analysis of Global Change; Academic Press: London, UK, 2020.

90. Reis, C.R.G.; Nardoto, G.B.; Oliveira, R.S. Global overview on nitrogen dynamics in mangroves and consequences of increasing nitrogen availability for these systems. Plant Soil 2017, 410, 1-19. [CrossRef]

91. Alongi, D.M. Impact of global change on nutrient dynamics in mangrove forests. Forests 2018, 9, 596. [CrossRef]

92. Thanh-Nho, N.; Marchand, C.; Strady, E.; Van Vinh, T.; Taillardat, P.; Cong-Hau, N.; Nhu-Trang, T.-T. Trace metal dynamics in a tropical mangrove tidal creek: Influence of porewater seepage (Can Gio, Vietnam). Front. Environ. Sci. 2020, 8, 139. [CrossRef]

93. Sadat-Noori, M.; Glamore, W. Porewater exchange drives trace metal, dissolved organic carbon and total dissolved nitrogen export from a temperate mangrove wetland. J. Environ. Manag. 2019, 248, 109264. [CrossRef]

94. Morel, F.M.M.; Hudson, R.J.M.; Price, N.M. Limitation of productivity by trace metals in the sea. Limnol. Oceanogr. 1991, 36, 1742-1755. [CrossRef]

95. Zhang, J. Evidence of trace metal limited photosynthesis in eutrophic estuarine and coastal waters. Limnol. Oceanogr. 2000, 45, 1871-1878. [CrossRef]

96. Sunda, W.G. Feedback interactions between trace metal nutrients and phytoplankton in the ocean. Front. Microbiol. 2012, 3, 204. [CrossRef]

97. Paerl, H.W.; Crocker, K.M.; Prufert, L.E. Limitation of $\mathrm{N}_{2}$ fixation in coastal marine waters: Relative importance of molybdenum, iron, phosphorus, and organic matter availability. Limnol. Oceanogr. 1987, 32, 525-536. [CrossRef]

98. Holmer, M.; Duarte, C.M.; Marbá, N. Iron additions reduce sulfate reduction rates and improve seagrass growth on organicenriched carbonate sediments. Ecosystems 2005, 8, 721-730. [CrossRef]

99. Brodersen, K.E.; Koren, K.; Mosshammer, M.; Ralph, P.J.; Kühl, M.; Santner, J. Seagrass-mediated phosphorus and iron solubilization in tropical sediments. Environ. Sci. Technol. 2017, 51, 14155-14163. [CrossRef]

100. Ruiz-Helpern, S.; Macko, S.A.; Fourqurean, J.W. The effects of manipulation of sedimentary iron and organic matter on sediment biogeochemistry and seagrasses in a subtropical carbonate environment. Biogeochemistry 2008, 87, 113-126. [CrossRef]

101. Van Langenhove, L.; Verryckt, L.; Bréchet, L.; Courtois, E.A.; Stahl, C.; Hofhansl, F.; Bauters, M.; Sardans, J.; Boeckx, P.; Fransen, E.; et al. Atmospheric deposition of elements and its relevance for nutrient budgets of tropical forests. Biogeochemistry 2020, 149, 175-193. [CrossRef] 
102. Barkley, A.E.; Prospero, J.M.; Mahowald, N.; Hamilton, D.S.; Popendorf, K.J.; Oehlert, A.M.; Pourmand, A.; Gatineau, A.; Panechou-Pulcherie, K.; Blackwelder, P.; et al. African biomass burning is a substantial source of phosphorus deposition to the Amazon, tropical Atlantic Ocean, and Southern Ocean. Proc. Nat. Acad. Sci. USA 2019, 116, 16216-16221. [CrossRef]

103. Strzelec, M.; Proemse, B.C.; Gault-Ringold, M.; Boyd, P.W.; Perron, M.M.G.; Schofield, R.; Ryan, R.G.; Ristovski, Z.D.; Alroe, J.; Humphries, R.S.; et al. Atmospheric trace metal deposition near the Great Barrier Reef, Australia. Atmosphere 2020, 11, 390. [CrossRef] 